مقايسه كارايى سامانهاى ردهبندى آمريكايى و جهانى در بررسى تغييرات خاكهاى واقع در موقعيتهاى مختلف شكل زمين

\author{
يُخاه خسروانى، مجيد باقرنزاد"، سيدعلى ابطحى و رضا قاسمى' \\ (تاريخ دريافت:
}

جكيده

طبقهبندى خاك در يك سيستم استاندارد عموماً طبق اطلاعات حاصل از اندازهيرى ويزّكىهاى خاك در واحدهاى نقشهبردارى مختلـف تعريـف

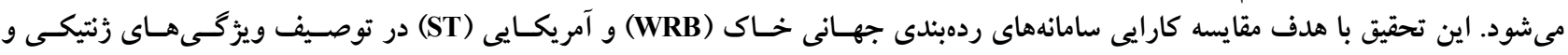

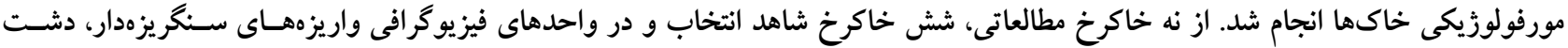

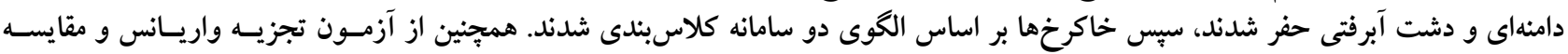

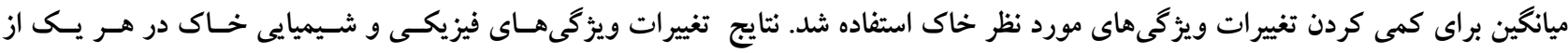

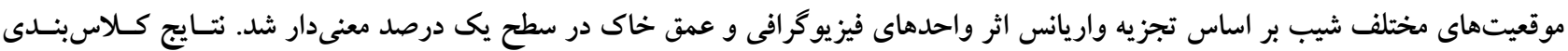

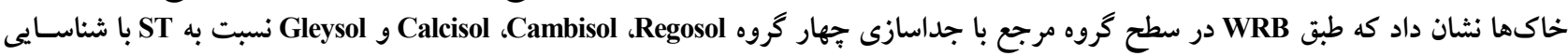

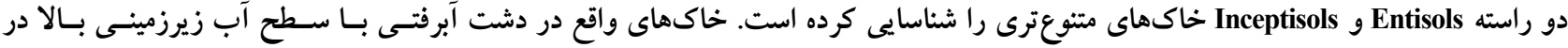

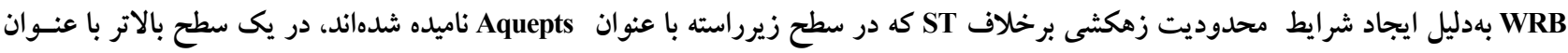

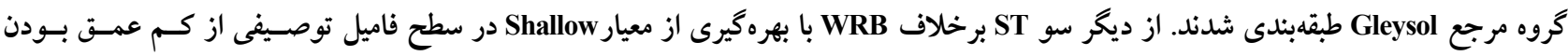

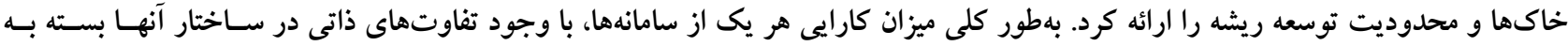

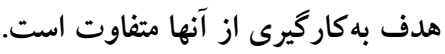

وازههاى كليدى: سطوح زئومورفيك، طبقهبندى خاك، كانىشناسى رس، ويزگىهاى مورفولوزيكى خاى 
موضوع اهميت كارايى و توانايى سيستم ردهبندى در نمايش

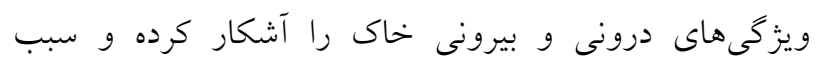

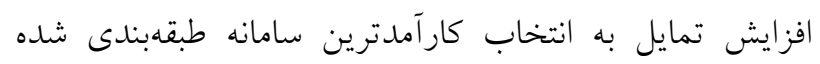

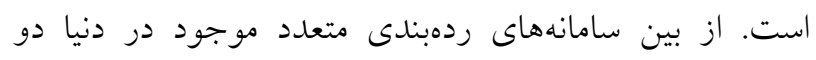

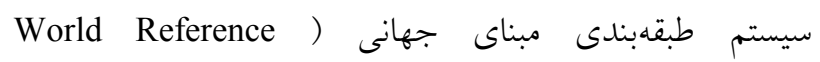
Soil و سامانه آمريكايى ردهبندى خاكهائ (WRB:Base نسبت به ساير روشهاى طبقهبندى از (ST: Taxonomy مقبوليت و استقبال بيشترى برخوردار هستند (YV). طبقهبندى

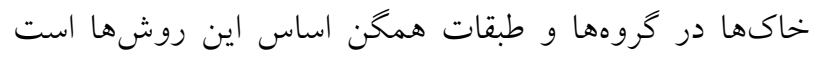

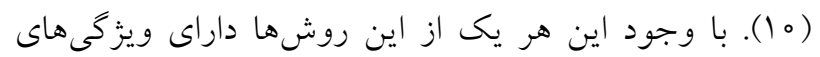
منحصربفرد در طبقهبندى است (N) كه سبب قوت و يا ضعف رتف آن در قبال اهداف مختلف يزوهشى و يا كاربردى است.

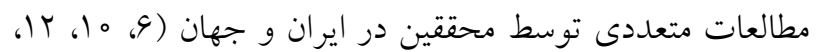

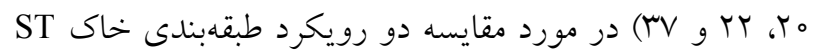
و بهB بنظور بررسى جالشها و كمبودهاى اين دو روش

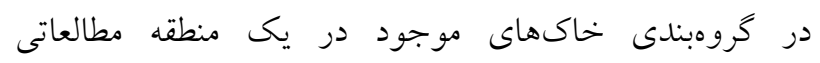

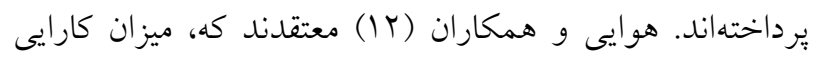

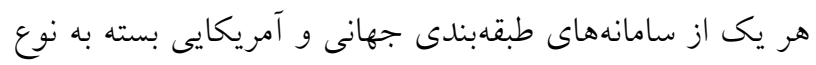

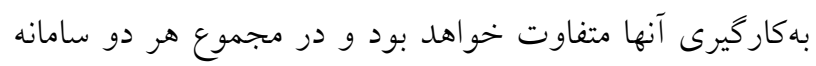

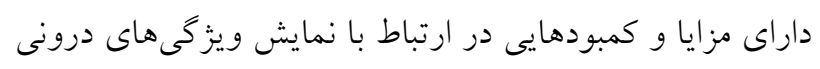

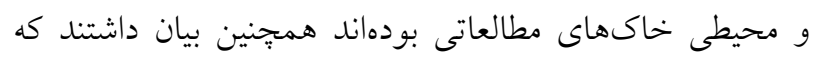

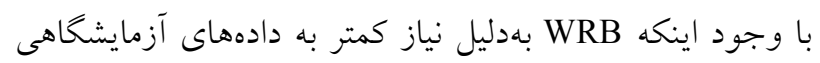

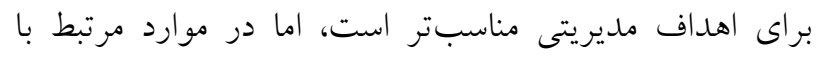

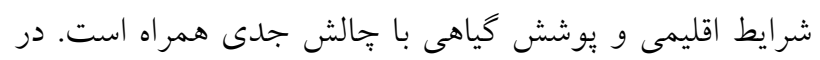

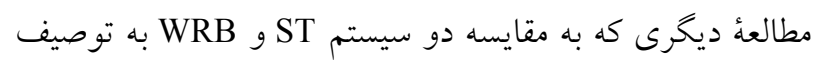

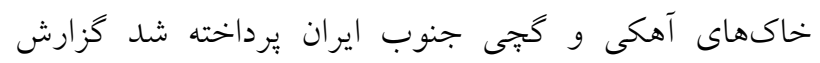

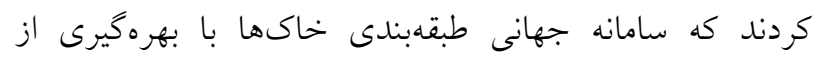
توصيف كنندهاى اصلى و مكمل در طبقدبندى خاكهاى منطقه مطالعاتى بهويزه خاكهاى شور بسيار مؤثرتر از ST عمل

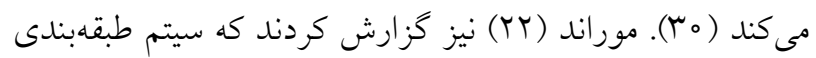
بهدليل داشتن الكوى طبقهبندى مناسبتر و تعداد گروه

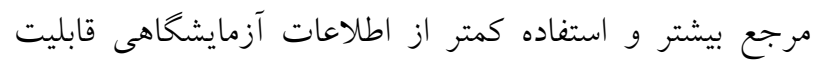

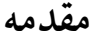

طبقهبندى خاكها در يك سيستم ردهبندى استاندارد، شامل ترسيم محدوده تغييرات خاكها روى واحدهاى نقشه، ذخيره اطلاعات حاصل از اندازهيرى خصوصيات خاكها در يك يايخاه داده و فراهم كردن شرايط لازم براى بيشبينى مناسب بودن يا محدوديتهاى آنها براى كاربرىهاى جندئانه با تأكيد

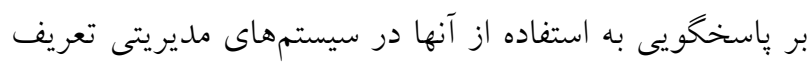

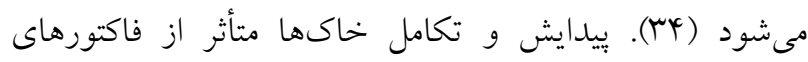
خاكسازى از قبيل تويوكرافى، مواد مادرى، اقليم، موجودات زنده و زمان است كه اين عوامل بهعنوان شرايط محيطى عمل كرده و در تشكيل و تكامل خاكهاى مختلف با درجه تكامل متفاوت نقش مهمى را ايفا مى كنند (ه|). مطالعات متعددى تحت عنوان تغييرات، تشكيل و تكامل خاكها در سطوح مختلف زئومورفيك (Geomorphic) توسط محققين در سراسر

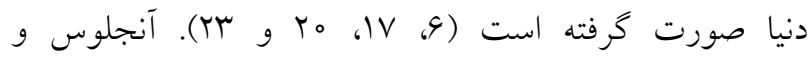
همكاران ( (1) با بررسى خاكهاى مختلف بيان كردند، كه شدت خاكسازى تا حد زيادى به خصوصيات سطوح زئومورفيك وابسته است و خصوصيات اين سطوح باعث تغيير در ميزان هواديدكى، ميزان شستشوى املاح محلول خاك، مراحل فرايندهاى شستشو و انتقال مواد، عمق تجمع املاح و درنهايت عمق سولوم مىشود. در كار سرمديان و همكاران (Y9) در واحدهاى زئومورفيك همخن مىتوان خاكهايى با ردهبندى و خصوصيات مشابه مشاهده كرد. بهدليل وجود همبستخى بالاى بين خاكها و واحدهاى سيماى اراضى (Tr) و فهم روابط بين فاكتورهاى تشكيل دهنده خاك، گروهبندى اين بهنههاى طبيعى بهوسيله يكسرى از كلاسهاى خاى با رفتار و ويزگىهاى مشابه مىتواند در رابطه با مديريت و استفاده از آنها مفيد و مؤثر واقع شود (ه). بنابراين طبقهبندى خاكها فعاليتى معنادار و هدفمند است. در اين راستا طبقهبندى خاك بهعنوان تكنيكى ارزشمند براى انتقال مفيد و مختصر مجموعه برحجمى از دادههاى خام و تجربه هاى كارشناسى (ه)، ابزارى ضرورى در يُهنها و برنامههاى مديريتى خاك محسوب مىشود. اين 
فرسايشى واحدهاى زمينما در مناطق فوقانى و رسوبخذارى آنها در بخشهاى ميانى و وِاى شيب است. اين رسوبات از

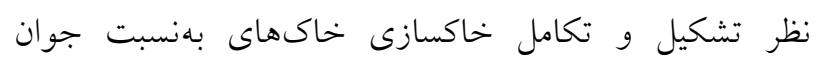
هستند و داراى توان حاصلخيزى بهنسبت مناسبى هستند.

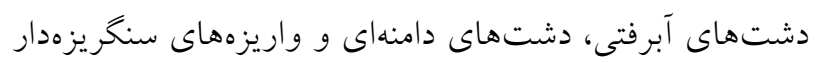

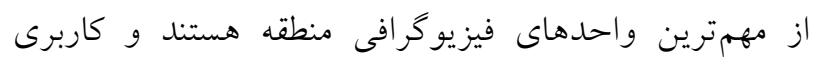

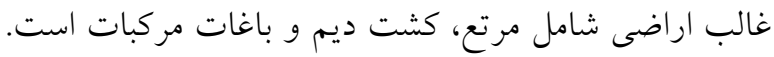

\section{مطالعات ميدانى و آزمايشخاهى}

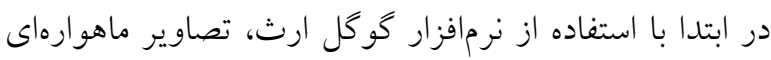

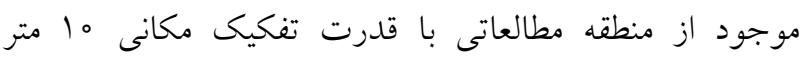

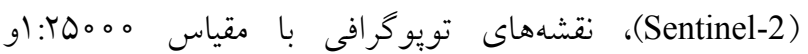
زمينشناسى موجود از منطقه با مقياس، مه000 1:1 مححدوده

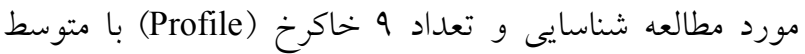
فاصله هم متر با روش مطالعه شناسايى آزاد در واحدهاى فيز يوكرافى شناسايى شده و تا عمق Y متر يا بالاى لايه محدوده

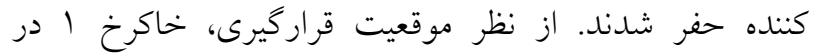

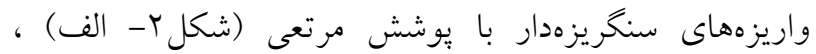

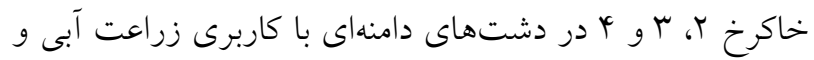
باغات مركبات (شكل r - ب) و خاكر خهاى ه، 9، V، 1 و 9 در

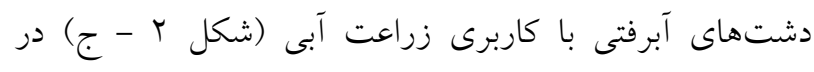
جهت شيب شمال شرقى به جنوب غربى تشريح و نمونه-

$$
\text { بردارى شد (شكل 1- ت ثلث ). }
$$

״ِ از تشريح كامل تمام خاكرخها بر اساس راهنماى تشـريح

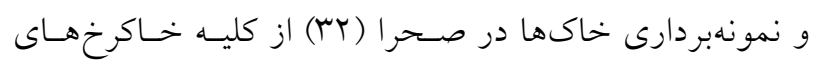

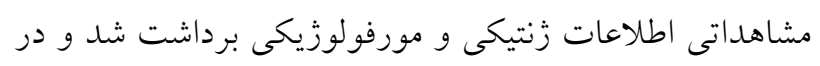

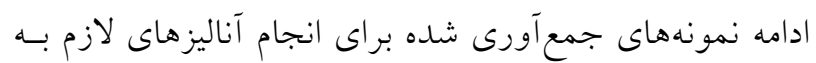

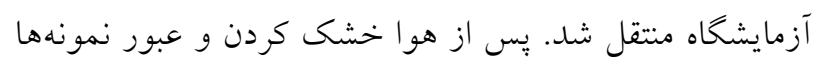

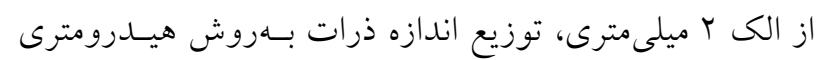

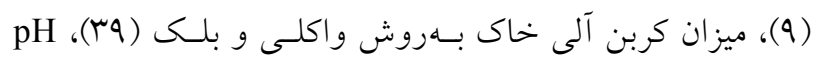

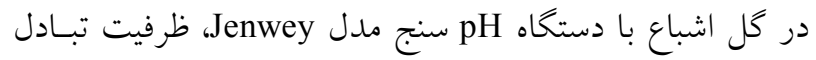
كاتيونى بهروش استات آمونيـوم (צب)، كربنـات كلسـيم معسادل
كاربردى و مديريتى بيشترى دارد. از طرفى روكا و يازوس (YV)

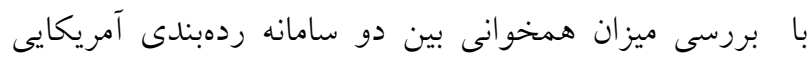

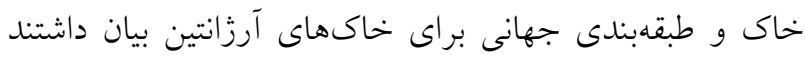
كه همبستخى بهنسبت خوبى بين اسامى خاك در سطح زيركروه با واحدهاى خاى تعريف شده در ST (Sub great group) سطح دوم سامانه طبقهبندى جهانى وجود دارد. اين تحقيق با بان

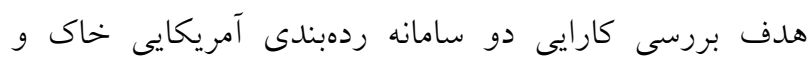

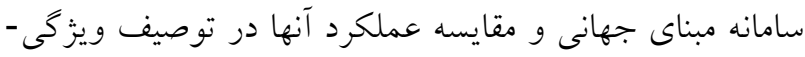

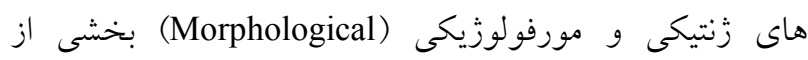
خاكهاى واقع در يكى رديف بستى و بلندى با اقليم گرم و

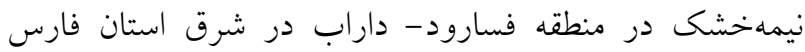
صورت كرفته است.

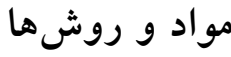

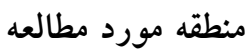
مطالعه حاضر در امتداد يك رديف يِستى و بلندى از اراضى

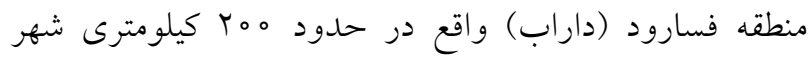

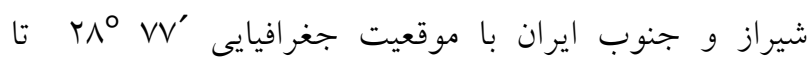
طول ${ }^{\circ}{ }^{\circ} V \Lambda^{\circ}{ }^{\circ}{ }^{\circ} V^{\prime}$ شرقى صورت يذيرفته است (شكل ا- الف و ا- ب). منطقه

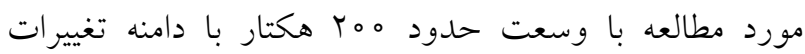

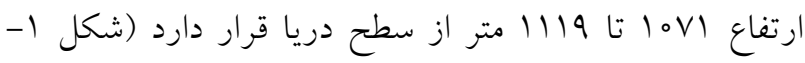

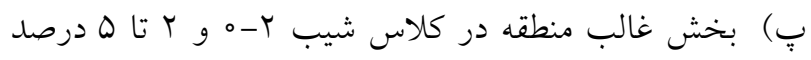

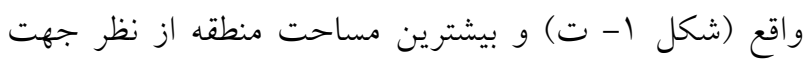

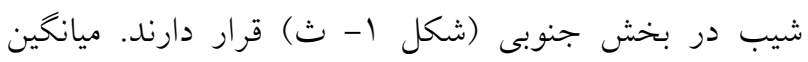

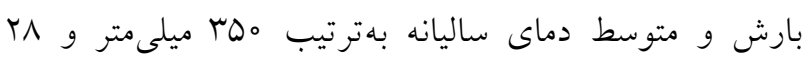
درجه سانتى گراد است (ץ) (1). منطقه مورد مطالعه داراى رزيم

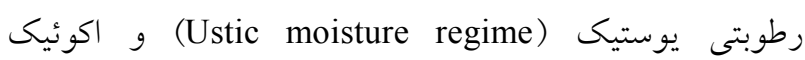
و رزيم حرارتى هاييرترميك (Aquic moisture regime) (Hyperthermic Thermal regime) تشكيلات زمينشناسى شامل نهشتههاى آبرفتى جوان و جديد

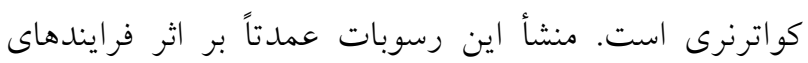




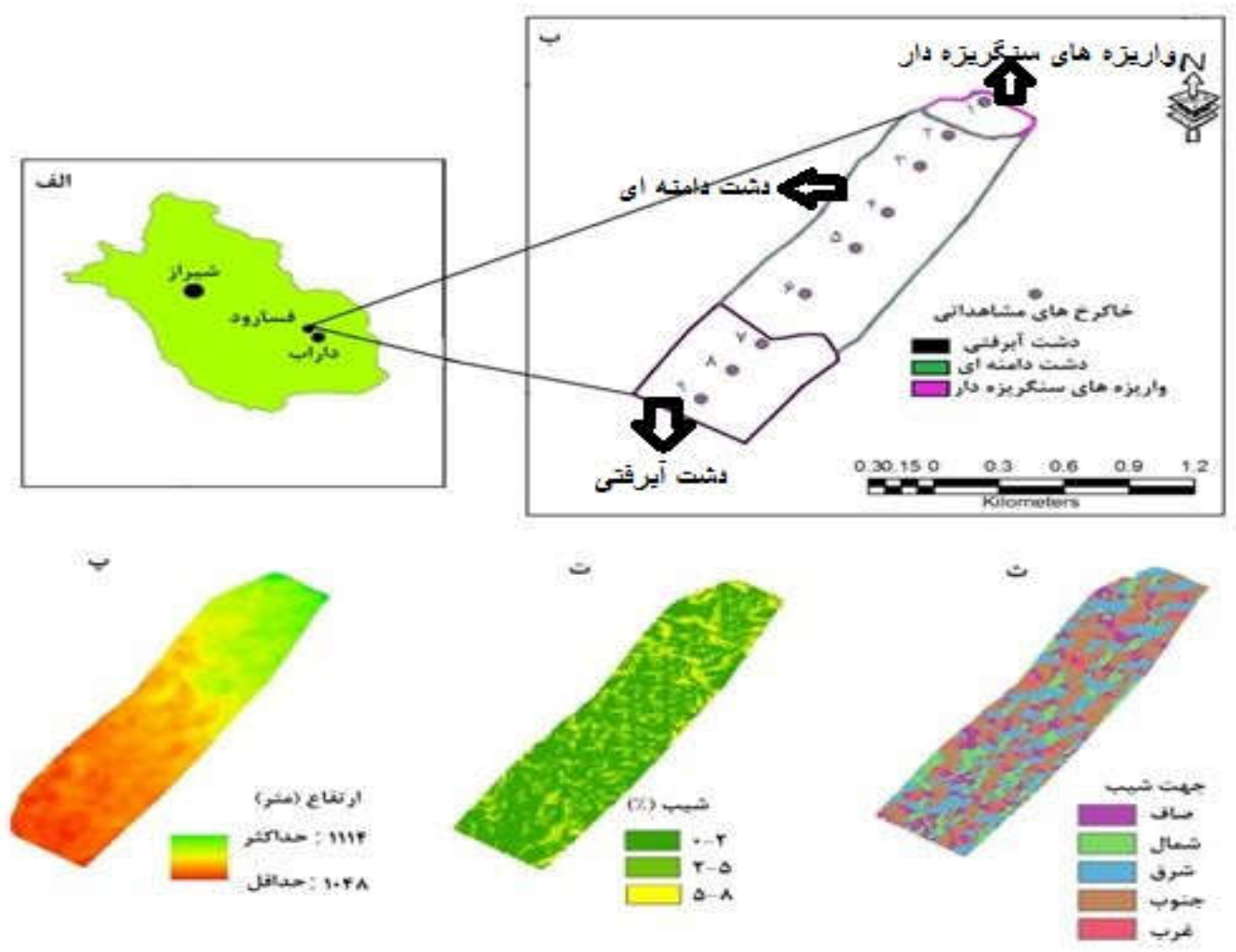

شكل ا. الف) موقعيت منطقه مطالعاتى نسبت به مركز استان، شهرستان داراب و شهر فسارود، ب) محدوده مطالعاتى و خاكرخهاى

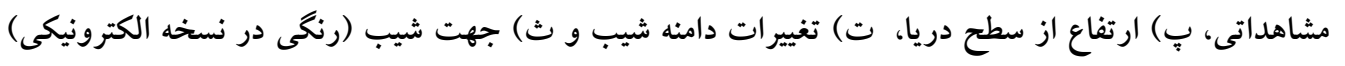

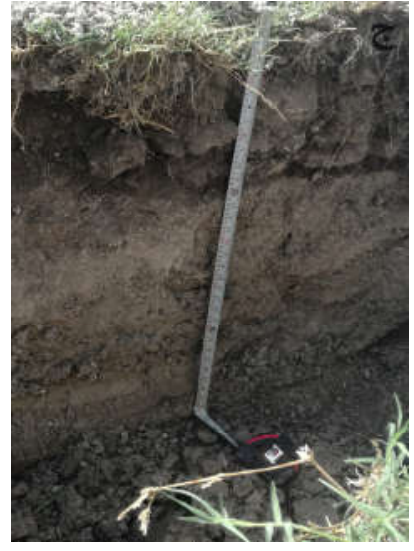

(ج)

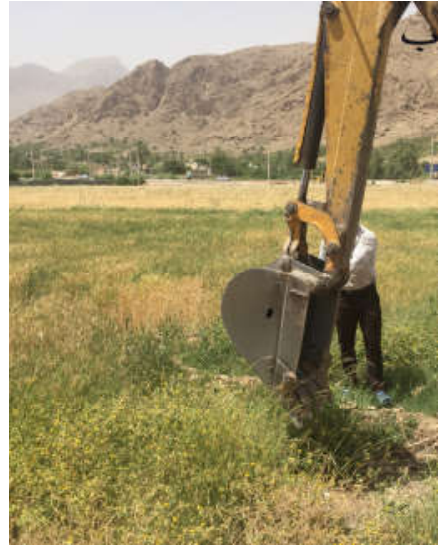

(ب)

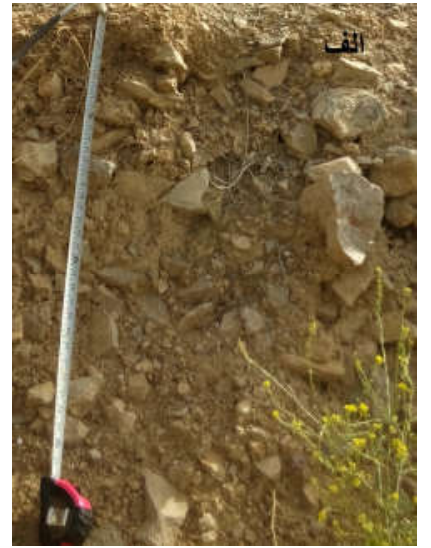

(الف)

شكل r. نمايى از خاكرخهاى حفر شده در هر يك از واحدهاى فيزيوگر افى (رخسارهها): الف) خاكرخ ا در واحد فيزيوگر افى واريزهاى

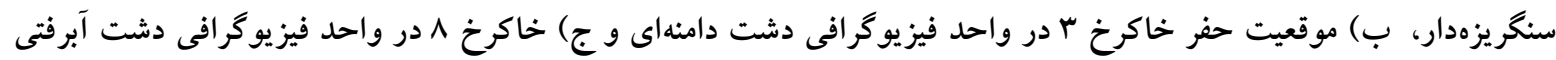


مرطوب، ساختمان خاك، جوشش با اسيد، تغييرات مرز

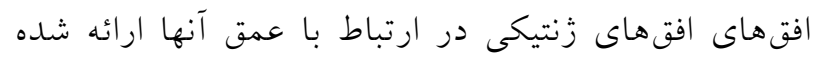

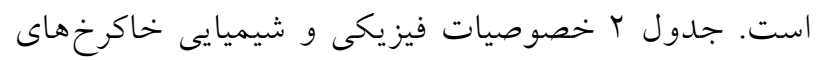
شاهد را به تفكيك نشان مى دهد. بافت خاك منطقه بهطور كلى سبك تا بسيار سبك بوده (بهجز خاكرخ خهاى 9 و 9 كه

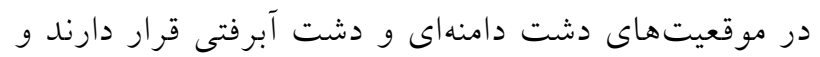

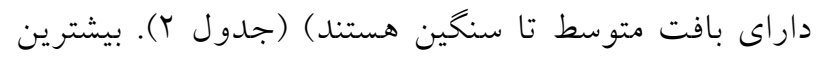
ميزان رس مربوط به خاكرخهاى 9 و 9 در موقعيت دشت بـائ

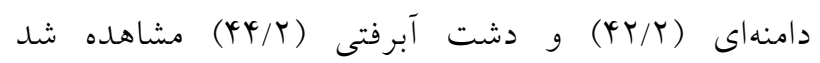

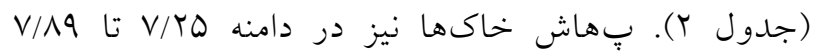

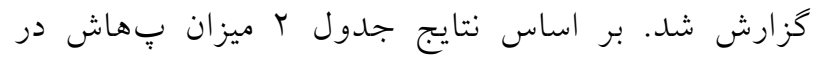

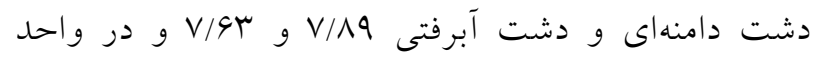

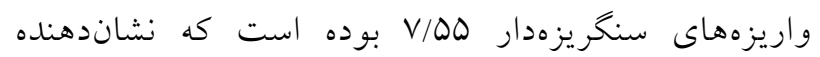
تجمع و يا انتقال املاح در اين دو واحد فيزيوكرافى نسبت به خاكرخ واقع در واحد مخروطافكنه سنكريزهدار است.

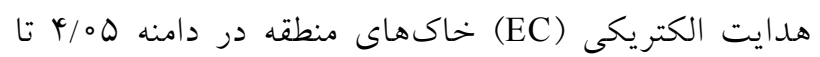
ه/r دسى هيمنس بر متر بوده است. خاك هاى شور منطقه در

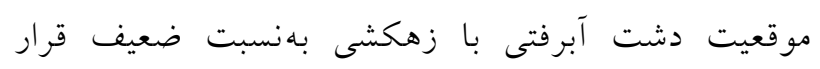

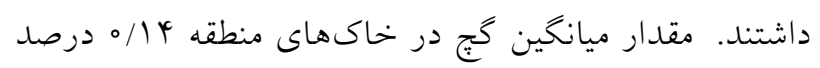

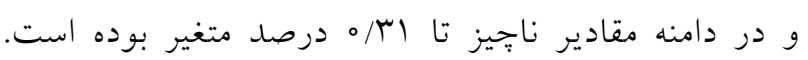

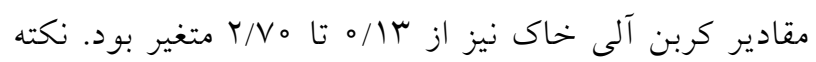

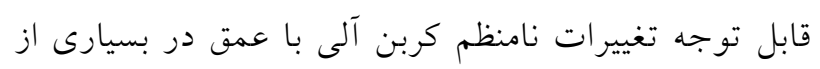

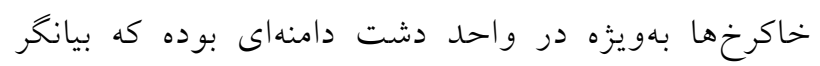

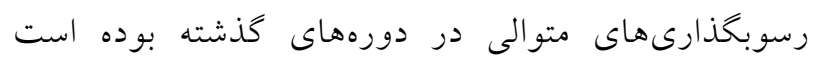

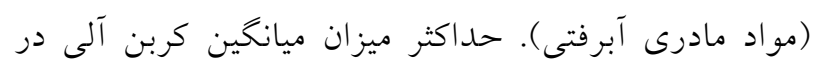

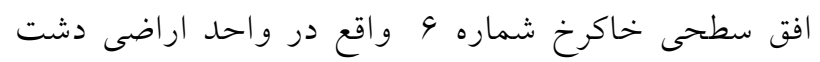

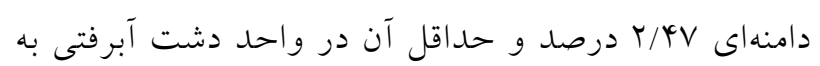

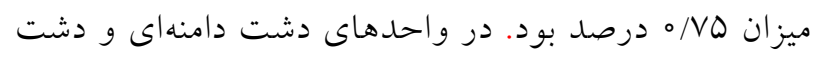

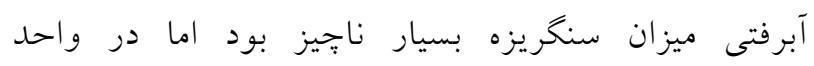

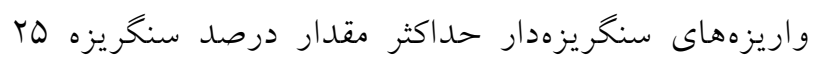

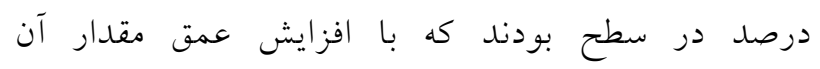

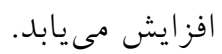

بلهروش تيتراسيون بركشتى (TO) و همجنين گج بهروش ترسيب

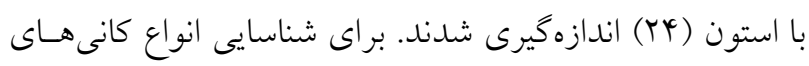

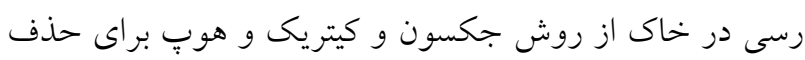
مواد سيمانى و جدا كردن بخش رس استفاده شد، و جهار تيمار

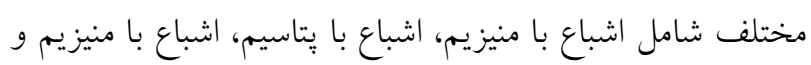

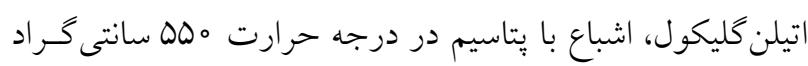

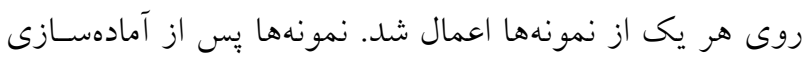

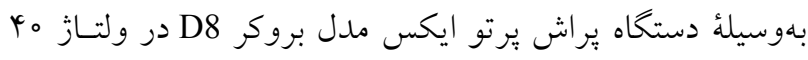

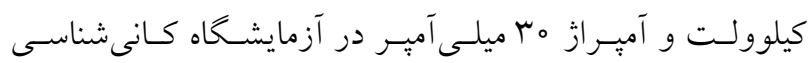

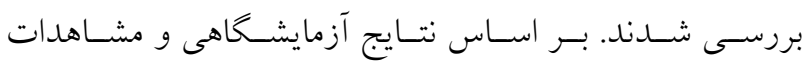

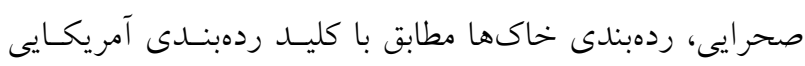
WRB و و سامانه طبقهبندى جهانى (soil survey staff, 2014) 2015) نهايى شد. تحليل آمارى در اين بخش از يزوهش براى ارائه نتايج دقيقتر و ارائسه نتـايج

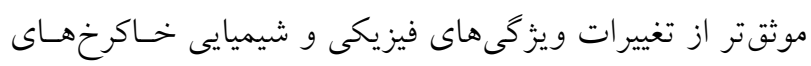

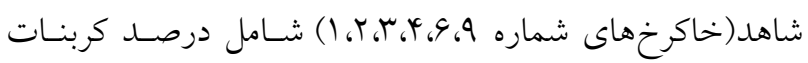

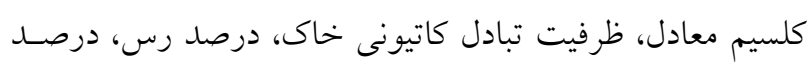

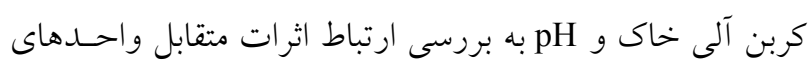

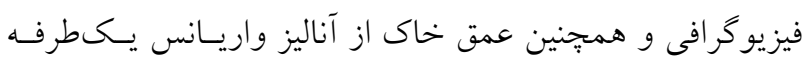

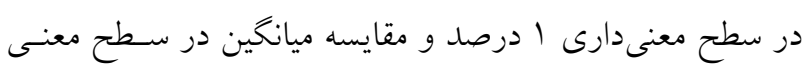

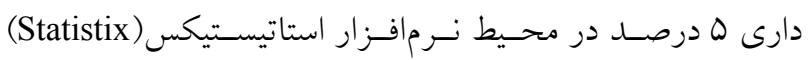

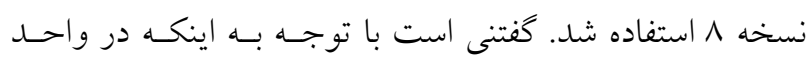

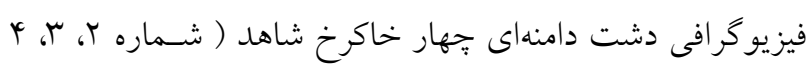

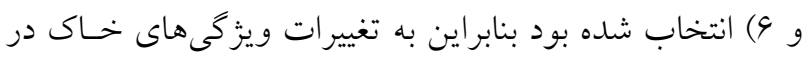
بين خاكرخهاى واقع در يك واحد فيزيوكرافى نيز برداخته شد.

\section{نتايج و بحث} ويزّى هاى فيزيكى و شميايى و مورفولوزيكى خاكرخهاى شاهد در جدول ا برخى از ويزگى هاى مورفولوزيك خاكرخهي ونهاى شاهد شامل وضعيت رنگ خاك در دو حالت خشى و 
جدول ا. ويزگى هاى مورفولوزيك خاكرخهاى شاهد

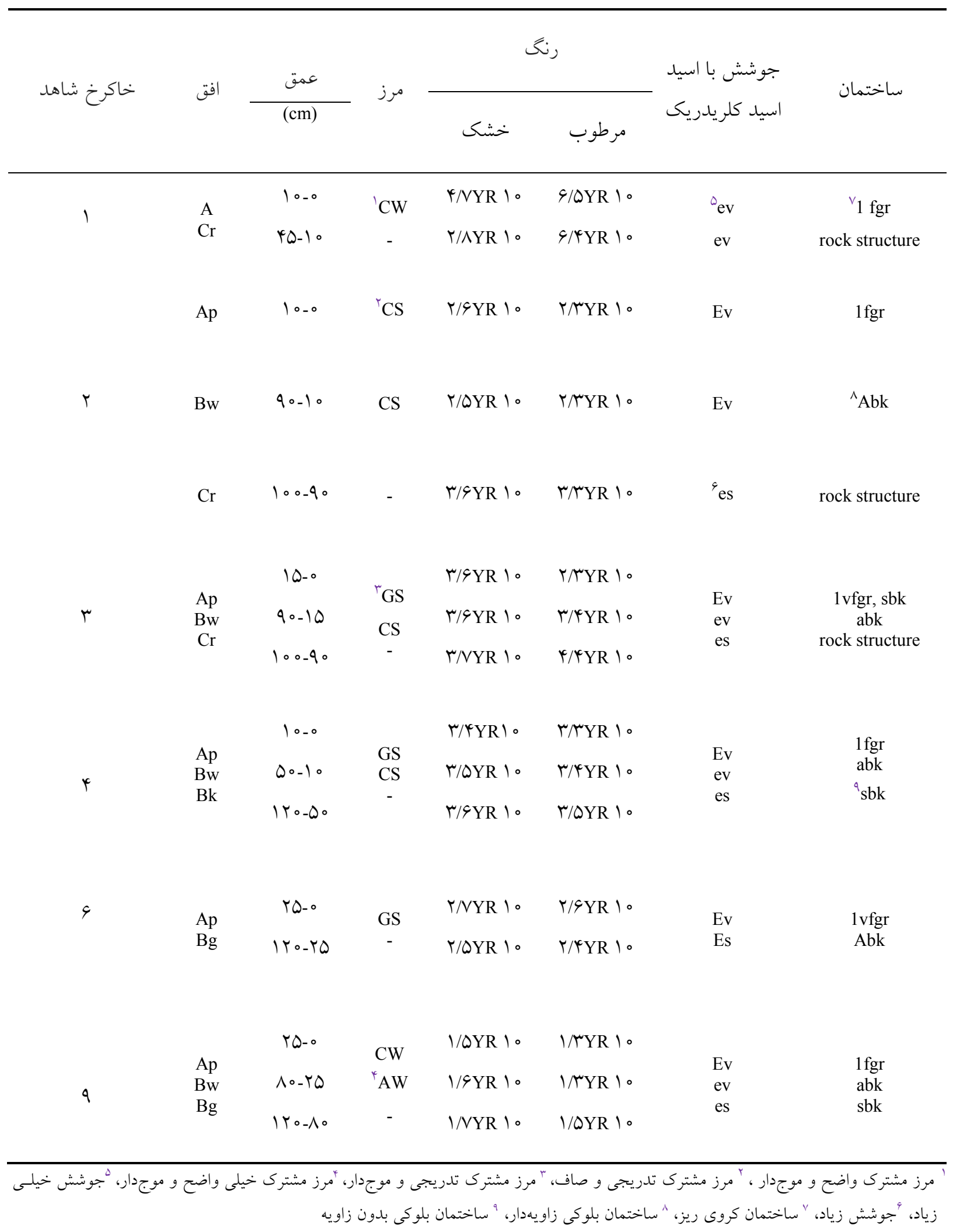


جدول r. خصوصيات فيزيكى و شيميايى خاكرخهاى شاهد

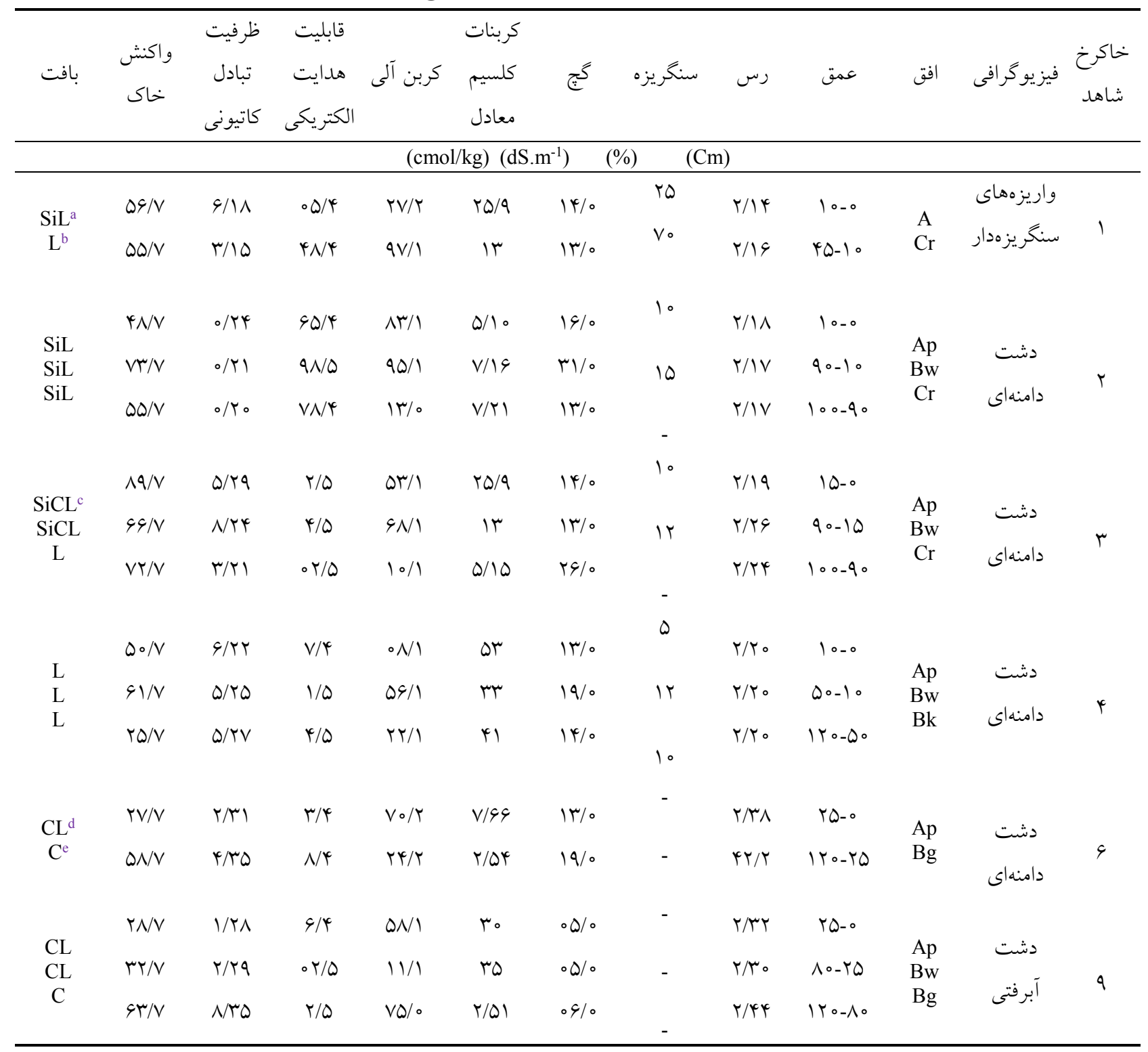

a Silty Loam b Loam c Silty Clay Loam d Clay Loame Clay

راستا با توجه به اينكه دو ويزگى درصد گج و قابليت هدايت الكتريكى داراى تغييريذيرى محسوسى در كل منطقه مورد

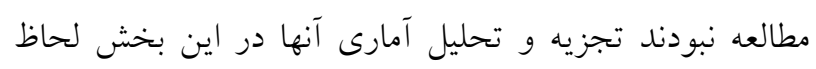
نشدهاست.

نتايج مقايسه ميانخين اثر نوع واحد فيزيوكرافى (واريزههاى

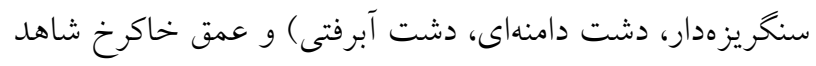

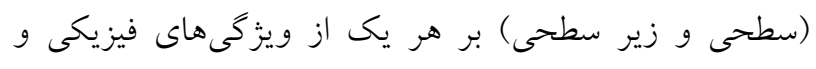

\section{تجزيه واريانس و مقايسه ميانخين}

بر اساس جدول ب نتايج تجزيه واريانس اثر واحدهاى

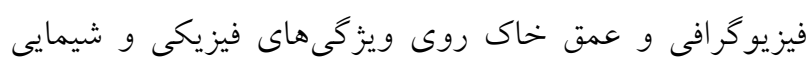

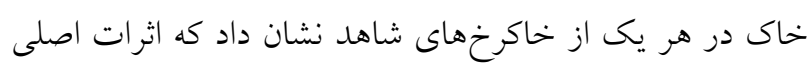

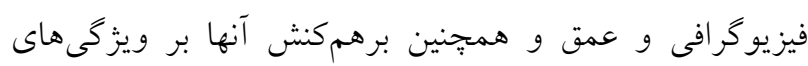

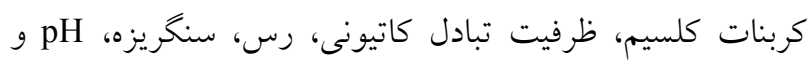
كربن آلى خاك در سطح يك درصد معنىدار است. در همين 
جدولr. نتايج تجزيه واريانس اثر متقابل واحد فيزيوگرافى و عمق بر ويزگىهاى فيزيكى و شيمايى خاك در هر يك از خاكرخهاى شاهد

\begin{tabular}{|c|c|c|c|c|c|c|c|}
\hline كربن آلى خاك & $\mathrm{pH}$ & سنكريزه & ل قرس & ظرفيت تبادل كاتيونى & كربنات كلسيم & درجه آزادى & منابع تغييرات \\
\hline $1 / r \mu q^{* *}$ & $\circ / \mid \Delta \wedge V^{* *}$ & $1911^{* *}$ & $4 a Y / 0^{* *}$ & $199 / 9^{* *}$ & $r \mu \wedge I^{* *}$ & 0 & فيزيوكرافى \\
\hline$\circ / 1 \vee \wedge^{* *}$ & $0 / 094)^{* *}$ & $900 / 0^{* *}$ & rN/ $/ r^{* *}$ & $\Delta / 4 \psi^{* * *}$ & $\wedge q / 4 q^{* *}$ & 1 & عمق \\
\hline$\circ / T Q 11^{* *}$ & $\circ / \circ \Delta \Delta V^{* *}$ & $r \Delta \Delta / \uparrow^{* *}$ & $\mid r / \sigma^{* *}$ & $11 / 90^{* *}$ & $\mid \Lambda \psi / \mu^{* *}$ & 0 & فيز يوكر افى لعمق \\
\hline \%OOrt & $0 / 0001$ & $\circ / 40$ & $\circ / \Gamma 4 \wedge$ & O/VOr & $1 / \Gamma V$ & rt & b \\
\hline$r / T r$ & o/Y & Y/AT & $r / 4 q$ & $r / \mu^{\prime}$ & $4 / 11$ & & ضريب تغييرات \\
\hline
\end{tabular}

كلئ خاكرخهاى واقع در سه واحد فيزيوگرافى بهجز در دو

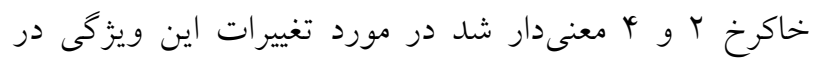

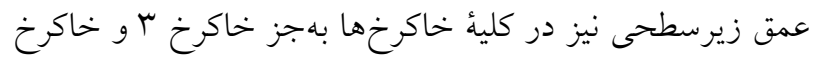

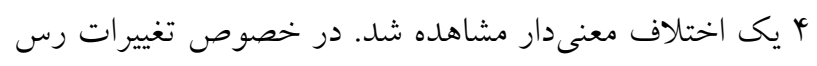

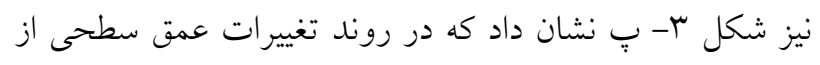

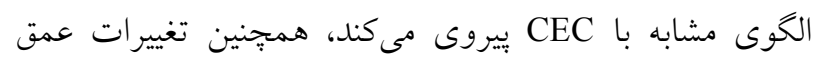

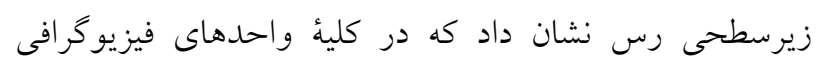

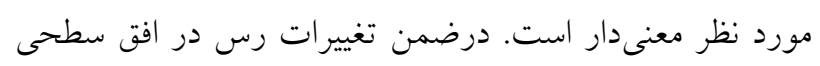

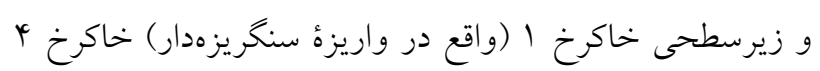

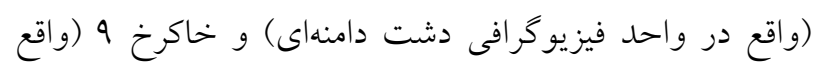

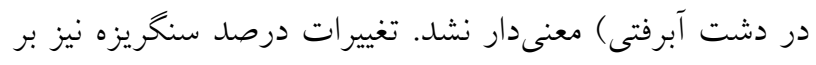

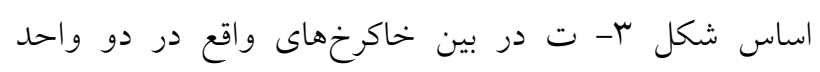

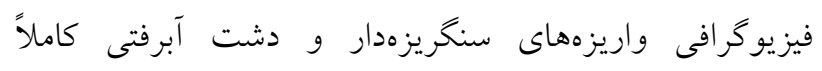

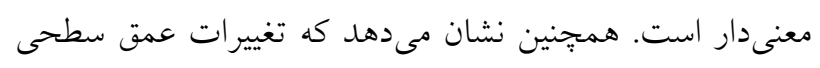

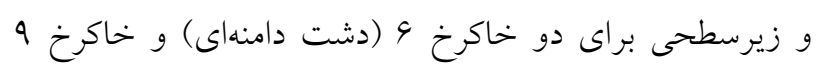

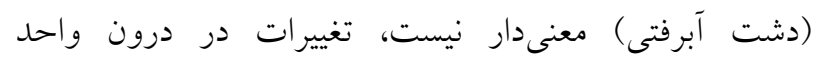

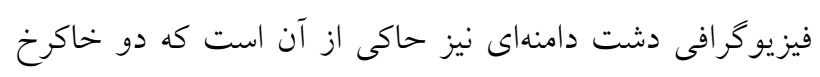

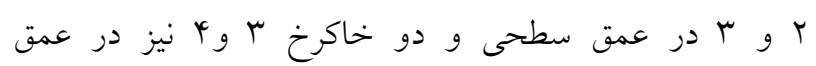

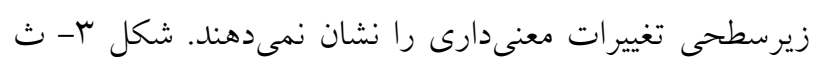

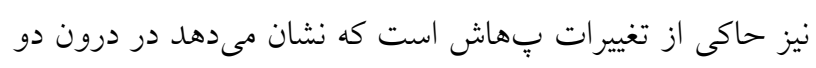

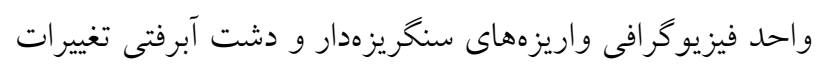

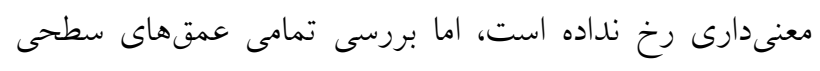

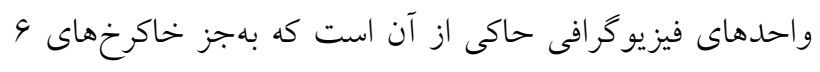

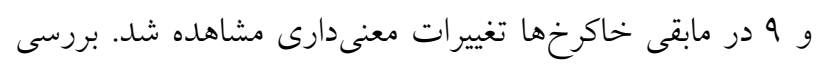

شيميايى مورد نظر با استفاده از آزمون LSD Lدر سطح

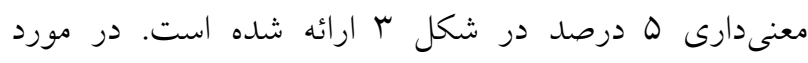

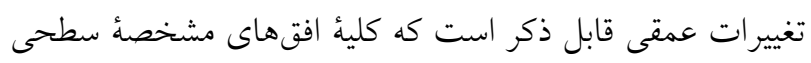
در اين تحقيق تحت عنوان "عمق سطحى" و مقادير ويزَكى هاى

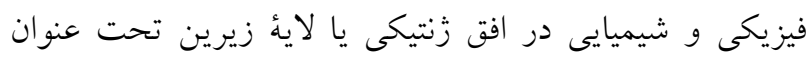

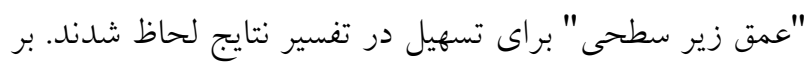

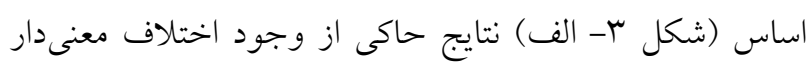

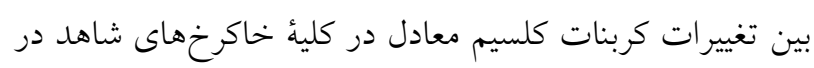
دو عمق سطحى و زيرسطحى است همجنين در مورد اثر

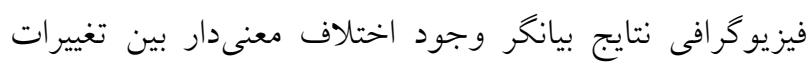

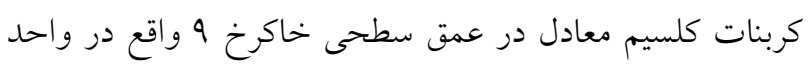

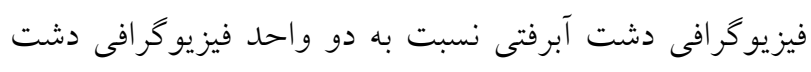

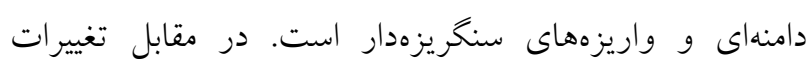

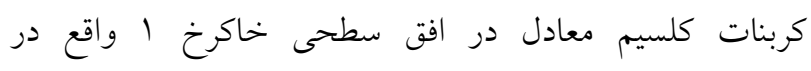

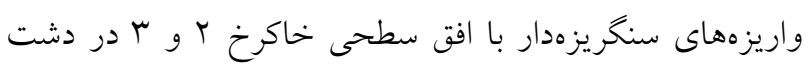

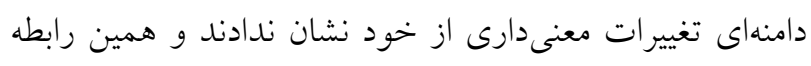

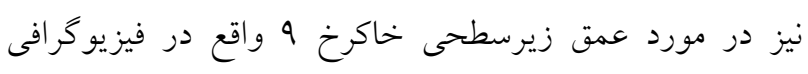

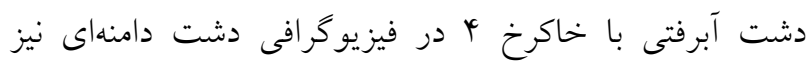

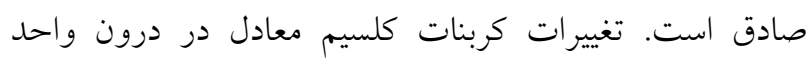

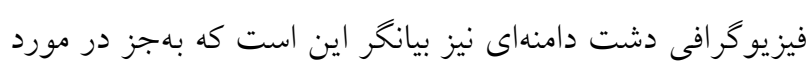

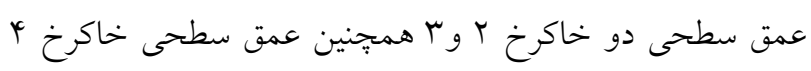
و عمق زيرسطحى خاكرخ 4 در مابقى عمقها تغييرات كربنات

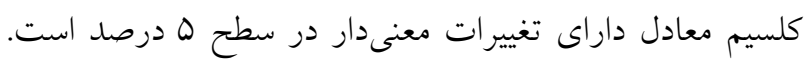

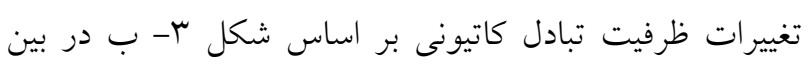


اثر و موقعيت شيب روى برخى ويزگىهاى فيزيكى و

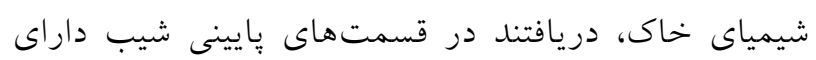

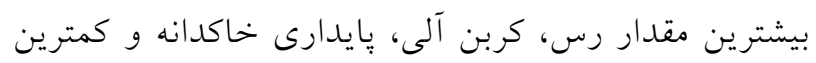

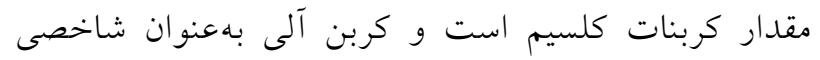
مناسب براى ارزيابى اثر موقعيت زمين نما بر كيفيت خاك اله

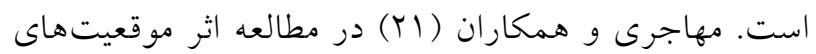

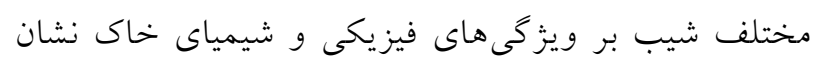

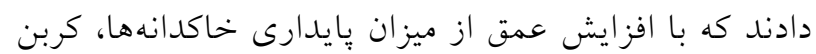

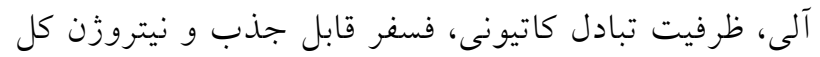

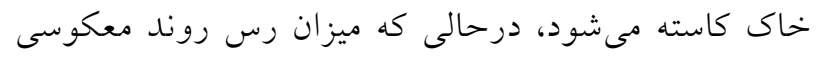

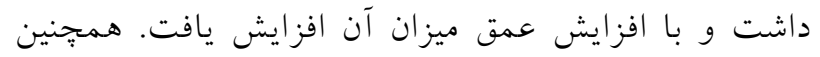

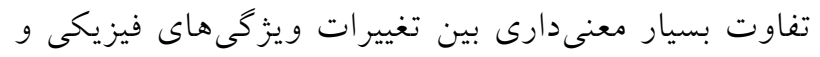

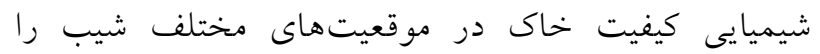
بهور عمده بهدليل تفاوت در ميزان رطوبت دريافتى، سرعت فرسايش و تجمع مواد نسبت دادند.

\section{مقايسه كاركرد دو سامانه ردهبندى}

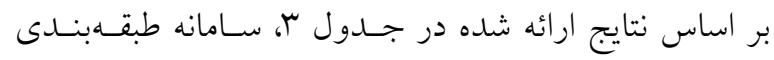

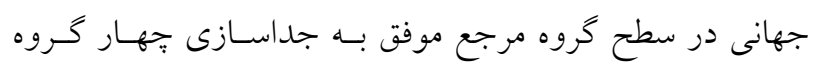

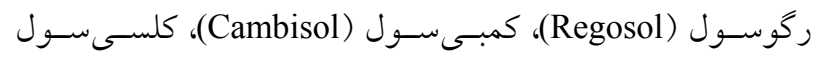

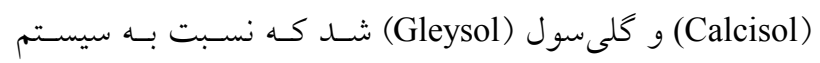

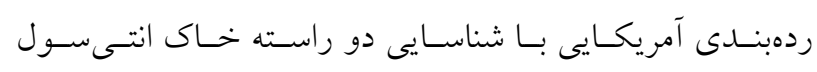
(Entisols)

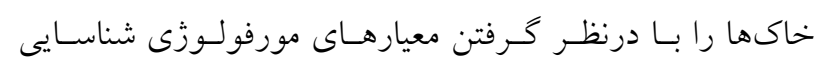

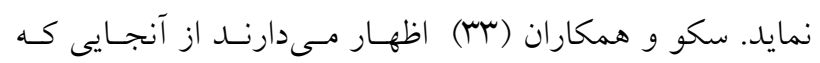

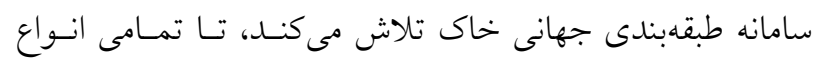

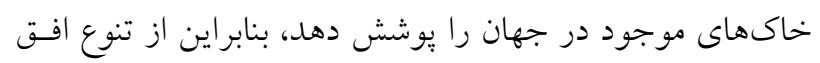
بالاترى نسبت به سامانه خاى آمريكايى برخوردار است و و تأكيد

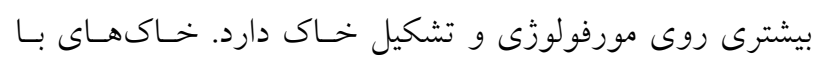

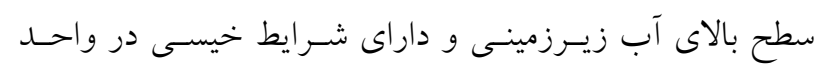

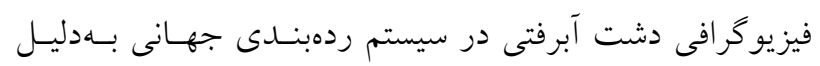

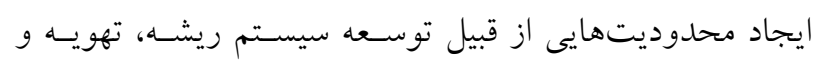

تغييرات عمق زيرسطحى نيز در هر سه واحد فيزيوكرافى نشان

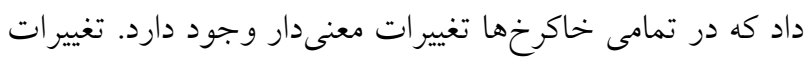

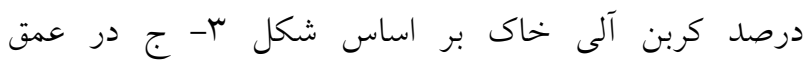

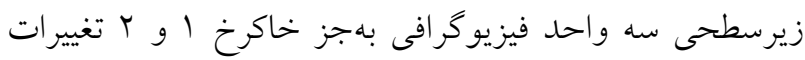

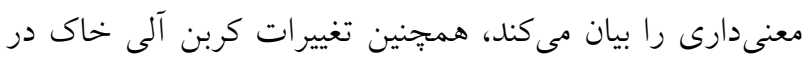

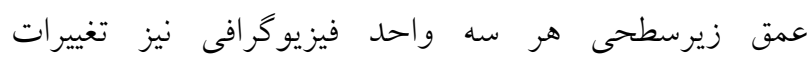
معنى دارى را براى تمام خاكرخ هما بهغير از بار و 9 نشان مى دهد.

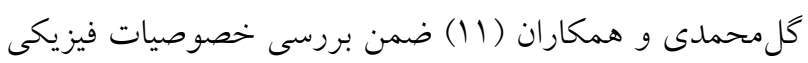
و شيميايى خاى (بֶهاش، كربن آلى، ظرفيت تبادل كاتيونى،

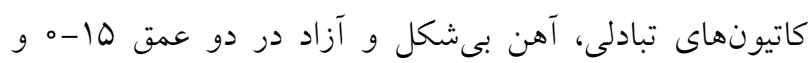

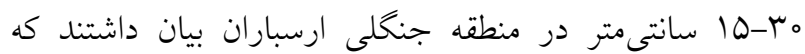
تغييرات خصوصيات فيزيكوشيميايى خاكهاى تشكيل شده روى موقعيتهاى مختلف شيب با مواد مادرى متنوع در هر دو

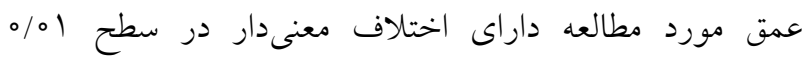

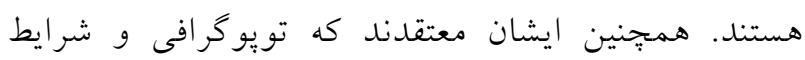
آب وهوا سبب اختلاف در نحوه تشكيل خاكهاى تشكيل

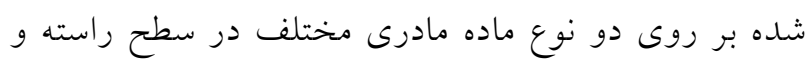

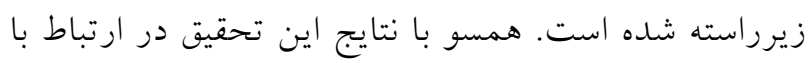

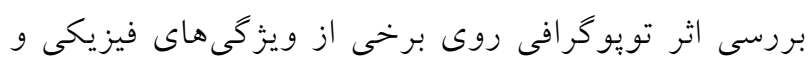

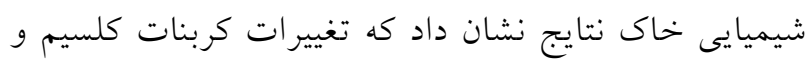
كربن آلى خاك در شيبهاى مختلف داراى اختلاف معنى -

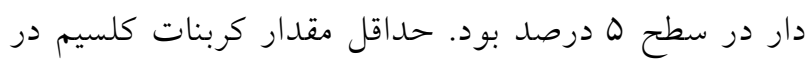

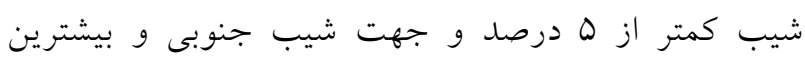

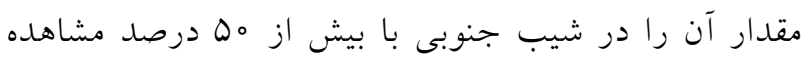

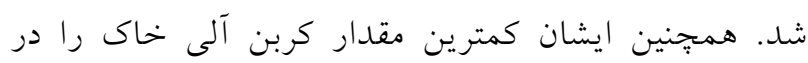
شيب بيش از مه درصد و بيشينه مقدار آن در شيب كمتر از

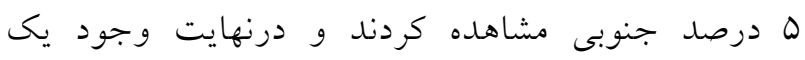

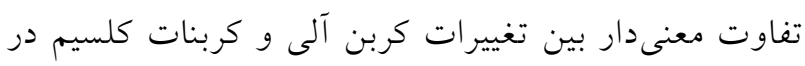
دو جهت شيب و در درجات مختلف شيب كزارش كردند.

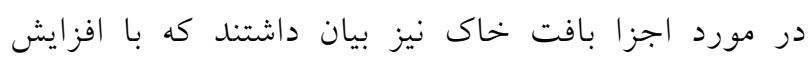
شيب درصد ذرات درشتتر افزايش و درصد ذرات ريزتر

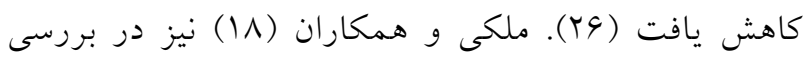


نشريه علوم آب و خاك / سال بيست و بنجم / شماره سوم / پاييز 1foo
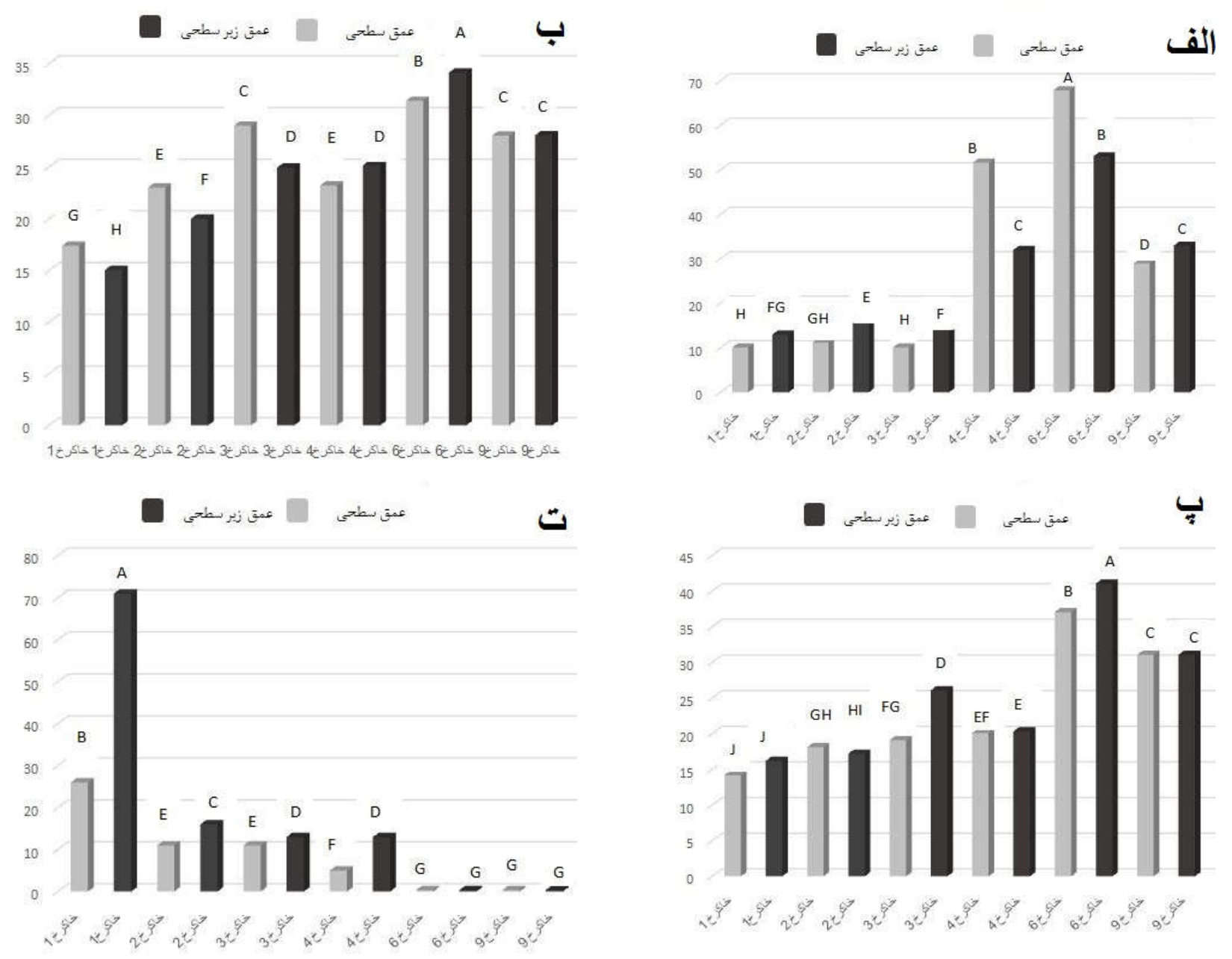

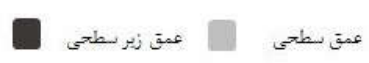

ج

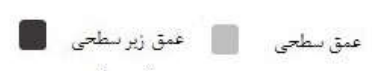

ث
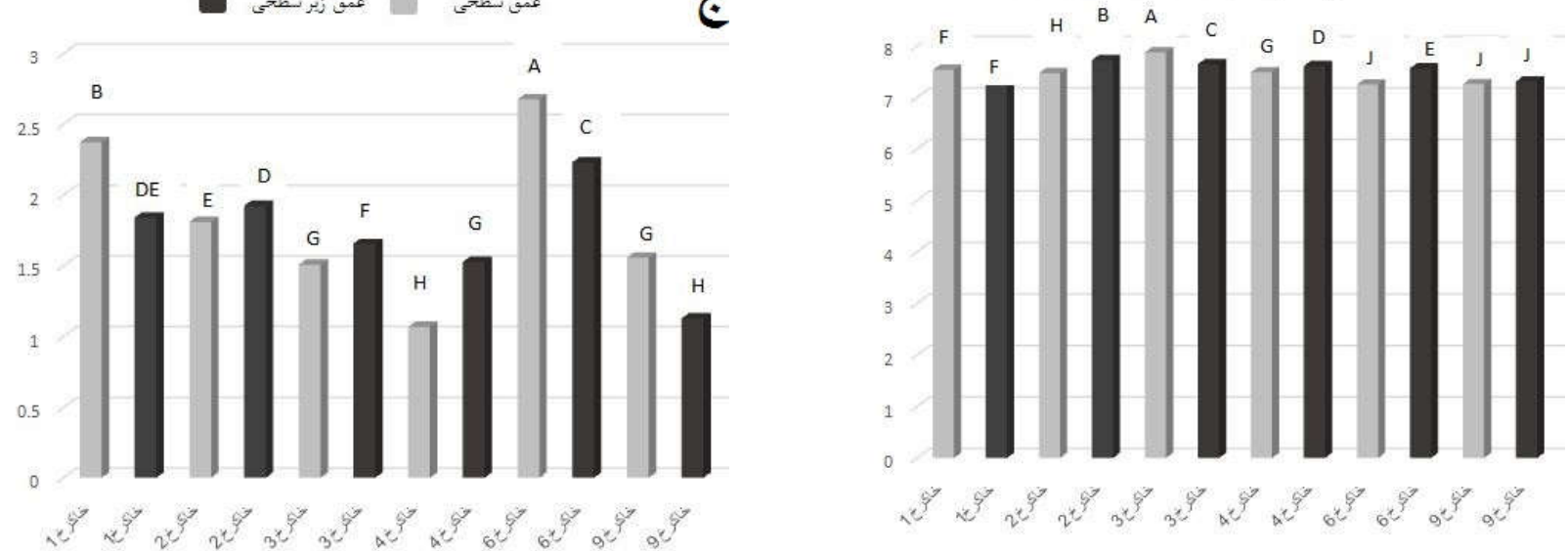

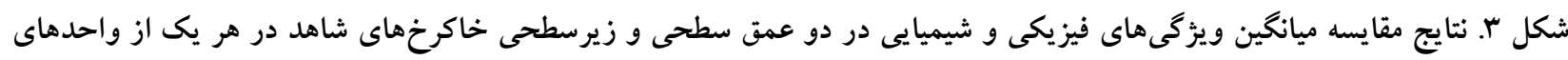

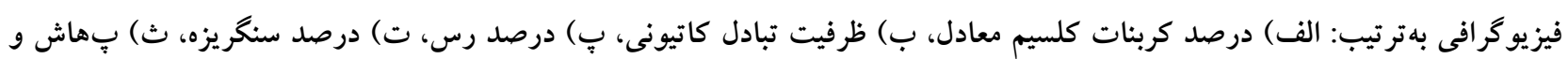
ج) درصد كربن آلى خاك 
بودن خاك را با معيار Shallow نشان داده استت. در مطالعهاى

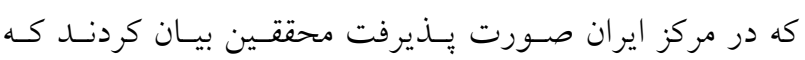

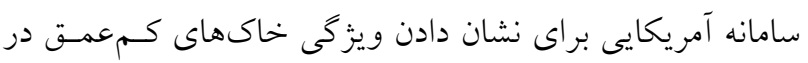

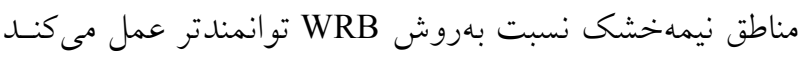

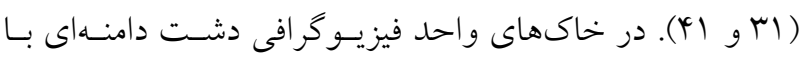

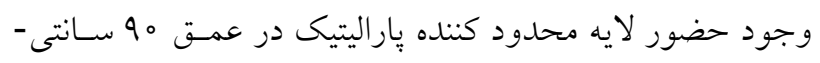
مترى (جدول () از سـطح خـاك در هـيج كـدام از دو سـامانه،

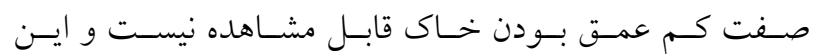
محدوديت روى رشد ريشه بهويزه در كياهان جند ساله از قبيـل

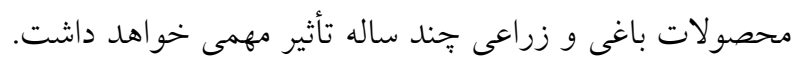

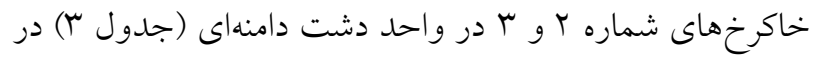
سطح زيركروه سامانه ردهبندى خاك آمريكـايى داراى تغييـرات

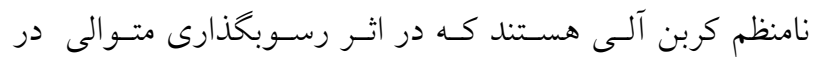
دورهاى مختلف فرسايش و رسوب بهوجود آمده اسـت كـه بـا

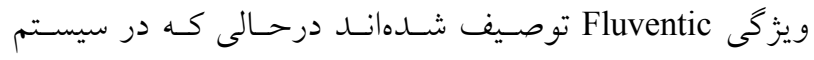
طبقهبندى جهانى اين مشخصه در هيج كدام از دو سـطح خـروه مرجع و توصيف كنندهاى اصلى و مكمل مشـاهده نمسى شـوده،

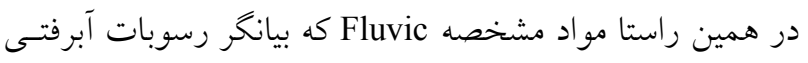

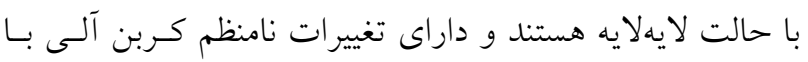

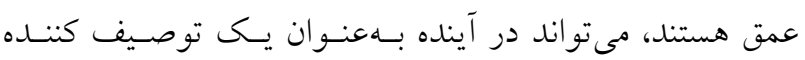

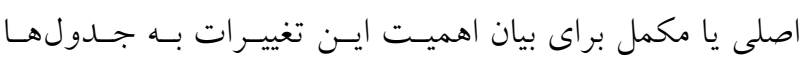

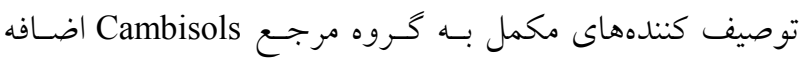

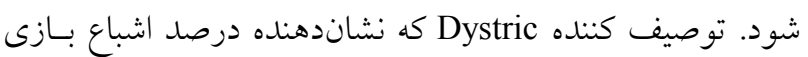

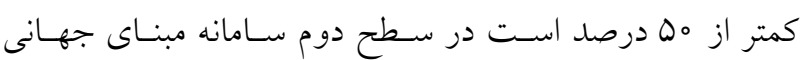

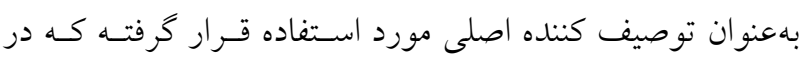

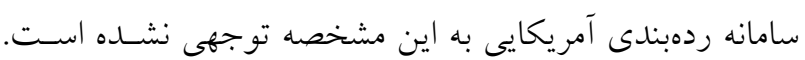

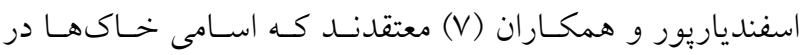
سامانه طبقهبندى جهانى، نسبت به ST، اطلاعات بيشـترى را در

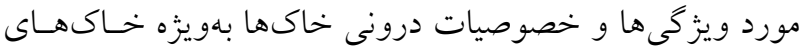

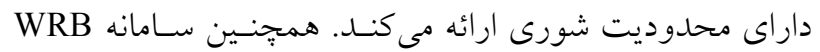

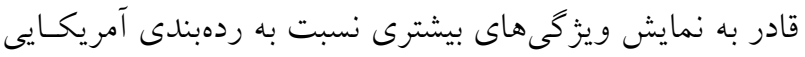

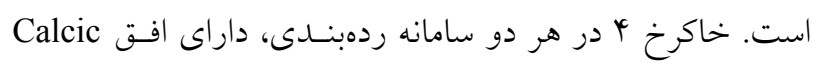

زهكشى خاك برخلاف روش ردهبندى خاك آمريكـيى كـه در

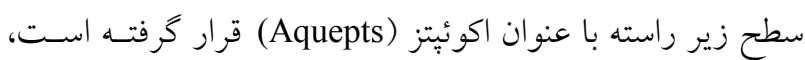
در يك سطح بالاتر با عنوان گروه مرجـع كلسىسـول (Gleysol)

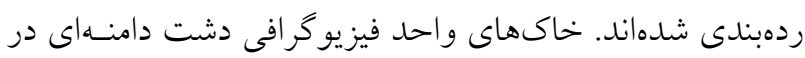

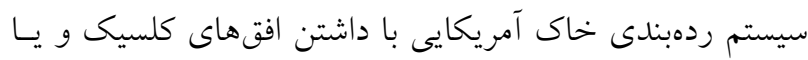

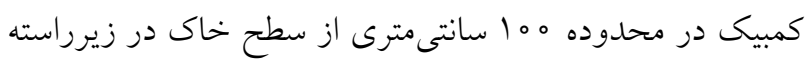

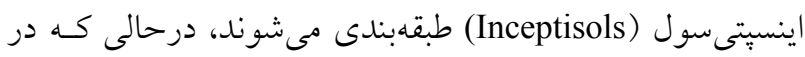

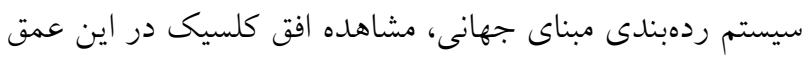
بهصورت يك كروه مرجع مجزا با نام كلسىسيسولز (Calcisol)

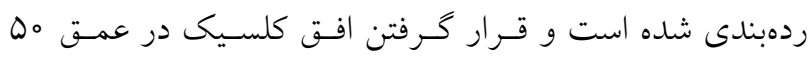
سانتىمتر از سطح خاك، اهميت حضور كربنات كلسيم و خطر

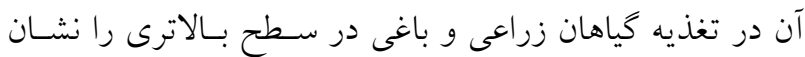

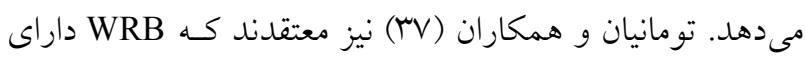

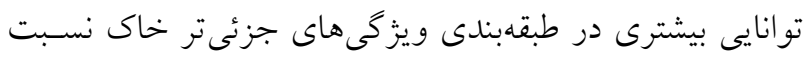

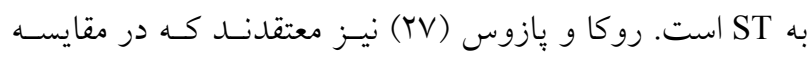

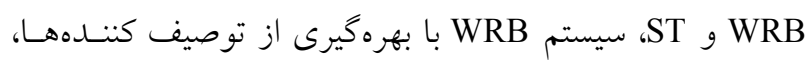

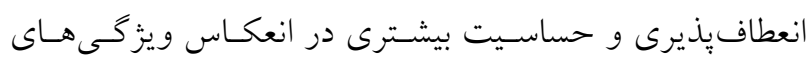

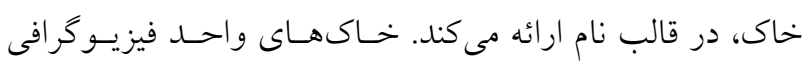

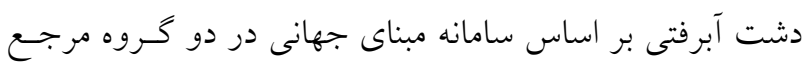

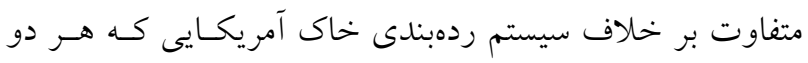

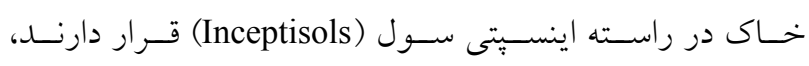

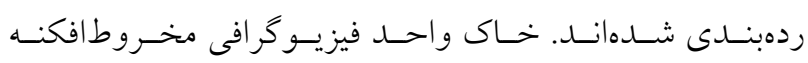

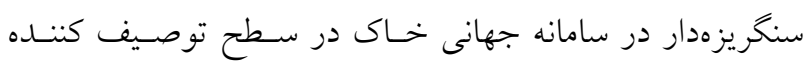

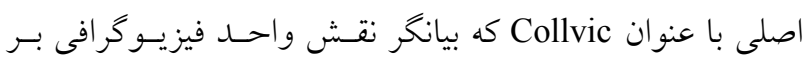

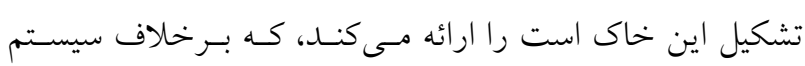

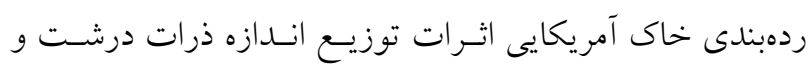

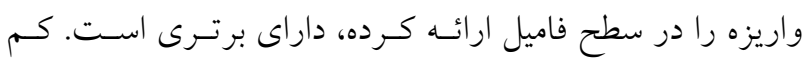

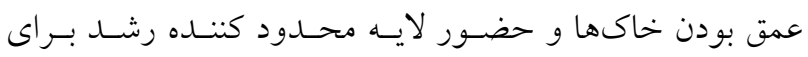
توسعه سيستم ريشه در سطح گروه مرجع و توصيف كنندهـاى اصلى و مكمـل در سـامانه جهانى خـاك مشـاهده نمسى تشعود،

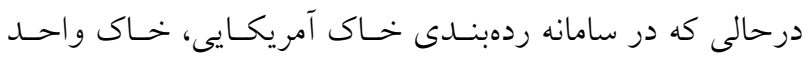

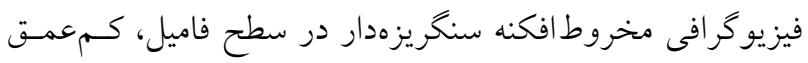


پِايين تر ردهبندى نيز تفاوتهاى جشمخيرى وجود دارد كه

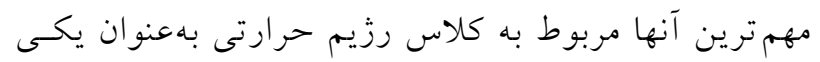

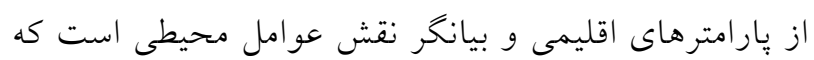

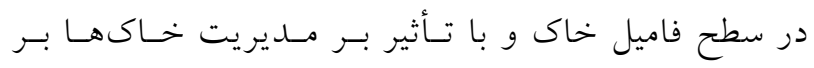
خلاف سيستم مبناى جهانى مورد استفاده قرار كرفته است.

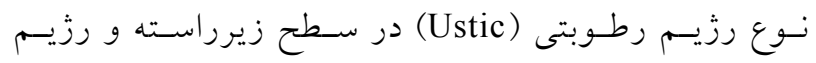

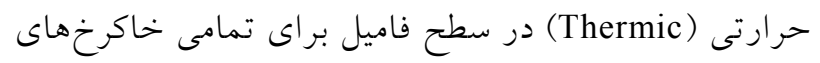

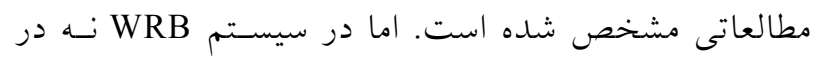

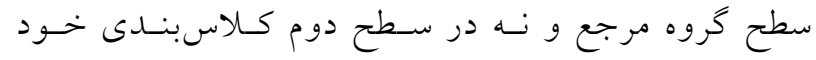

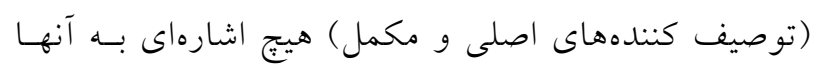

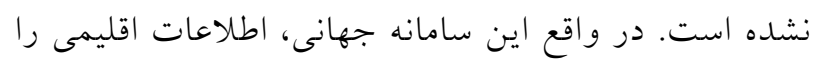
فقط براى تفسير نتايج شناسايى خاك به كار مى گيسرد (Yo (Y).

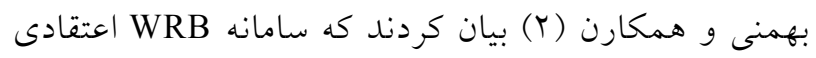

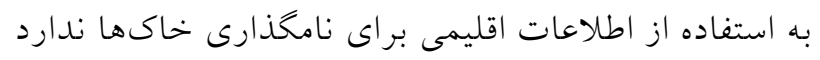

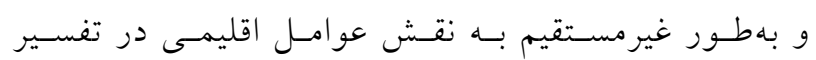

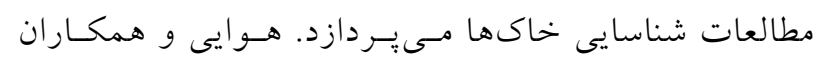

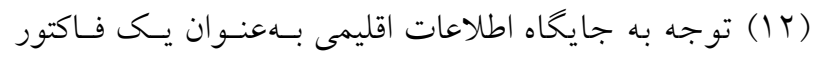

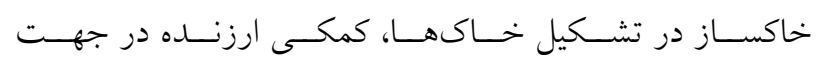

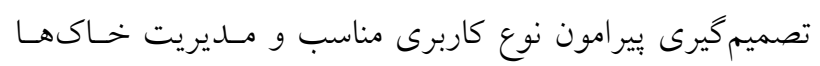

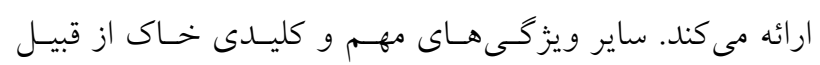

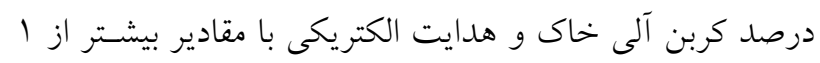

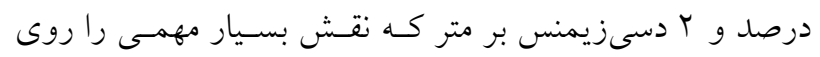

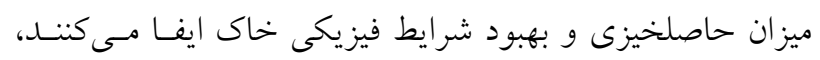

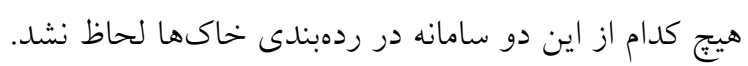

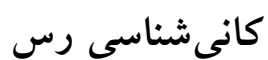

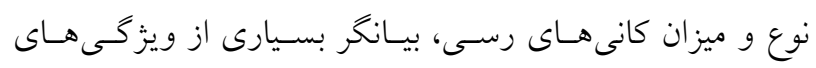

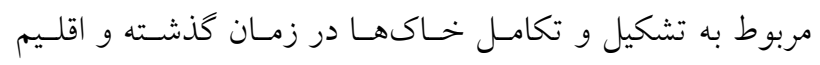

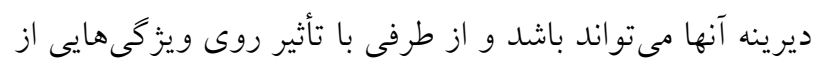

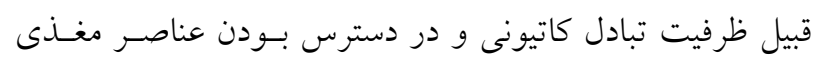

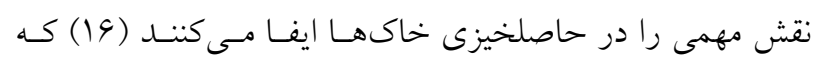

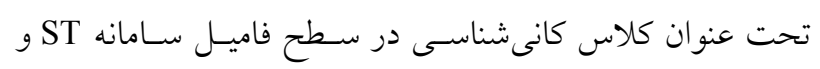

در مـرز بـالاى ه 10 سـانتى متـرى از سـطح خـاك هسـتند، امـا ردهبندى آن طبق ST در سطوح بالاى ردهبندى متفـاوت اسـت

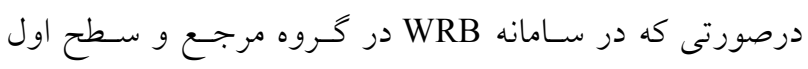
ردهبندى مو رد اشاره واقع شده است. نتسايج مشـابهى در همسين

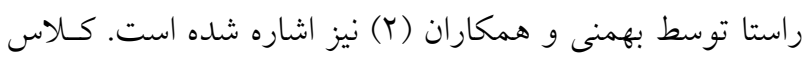
كانىشناسى بخش رس خاك بـهميـراه كـلاس فعاليـت تبـادل

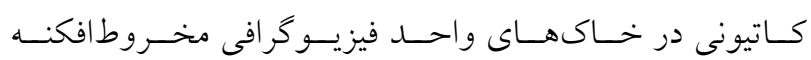
سنخريزهدار و دشت دامنهاى در سطح فاميل بهصورت mixed و superactive ردهبندى آمريكايى بر خلاف سيستم جهانى مورد بررسى قـر مرار

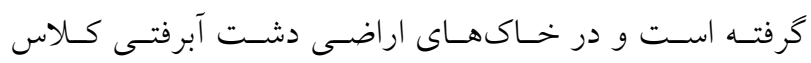

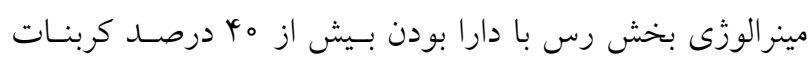

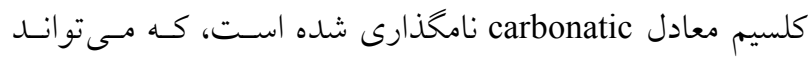
نشاندهنده برترى ST در نشان دادن ويزّكى هاى مديريتى خـاك

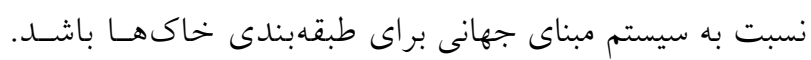

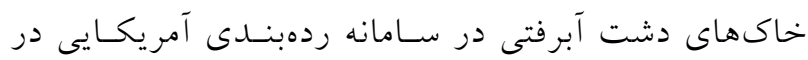

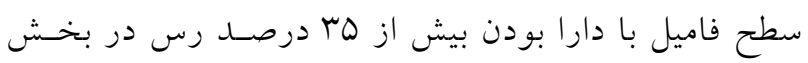

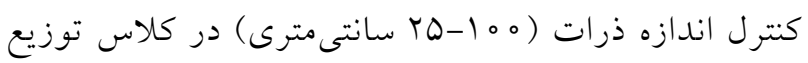

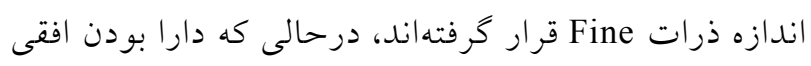

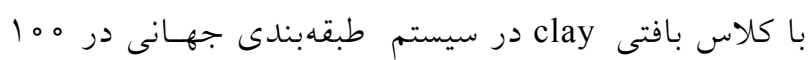

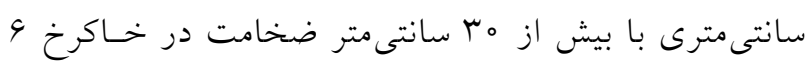

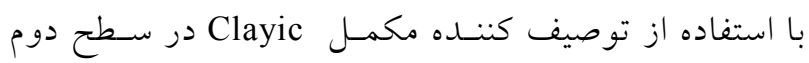
طبقهبندى بر خلاف سامانه ردهبندى آمريكايى كه در سطح

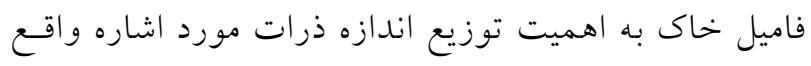
مىشود، بلافاصله در سطح دوم ردهبندى لحاظ شده اسـت.

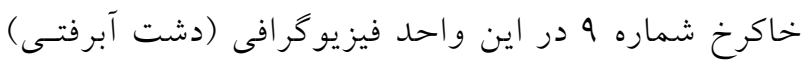

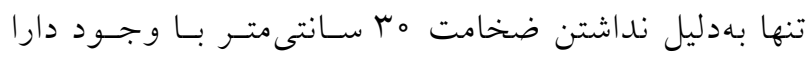

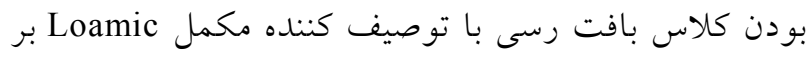

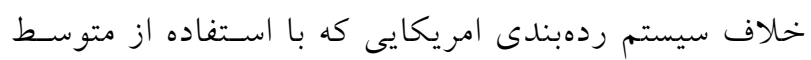

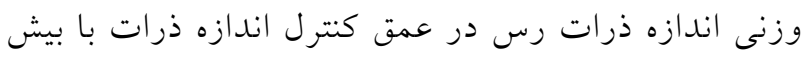

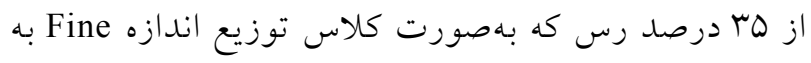

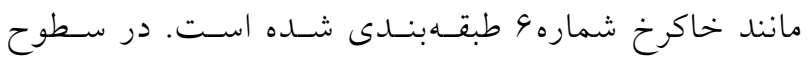


9 بهصورت مشترى كانى باليخورسكايت مشاهده شد اما كلاس

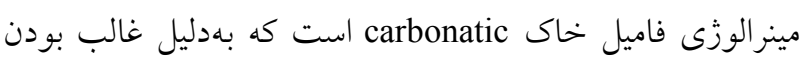

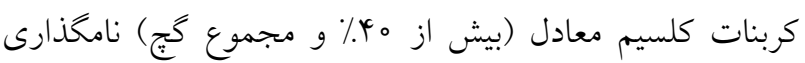

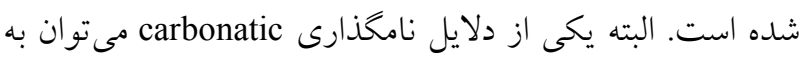

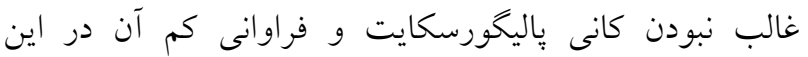

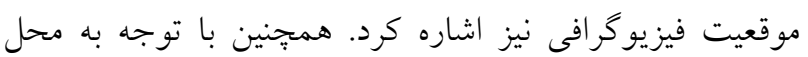

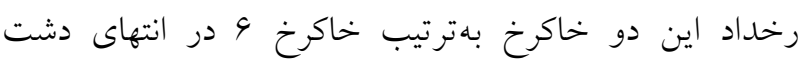

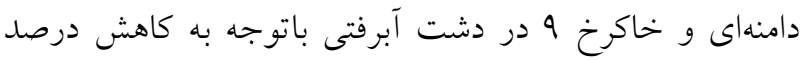

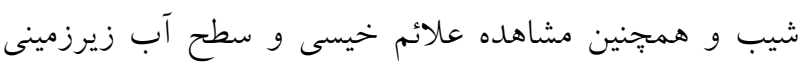
بالا بر اساس مشاهدات ميدانى معاذالهى و فريور (19) نيز بيان داشتند كه كانى باليكورسكايت بهدليل همراهى با كريستالهاى

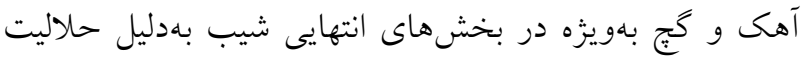
بالاى گَج و همجنين خيسى خاك مشاهده نشد. در همين راستا

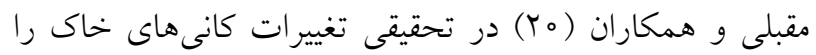
در يك منطقة خشى در جنوب استان كرمان روى اشكال

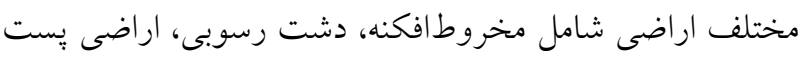

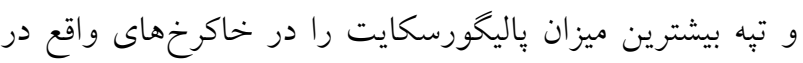

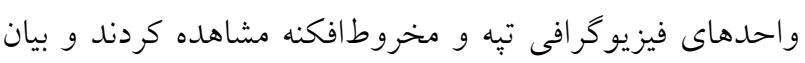

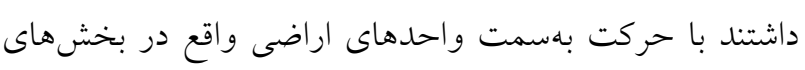

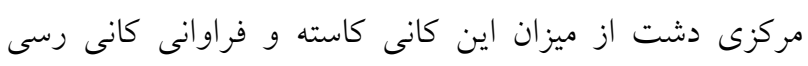

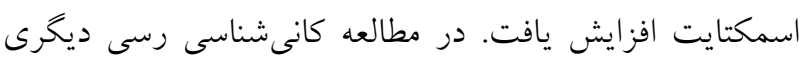

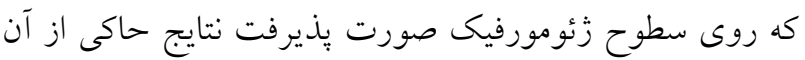

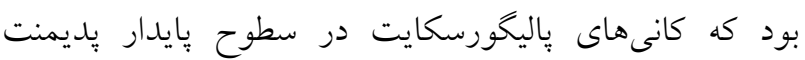

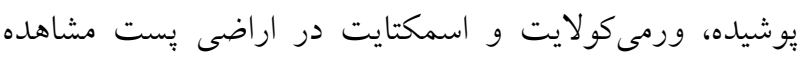

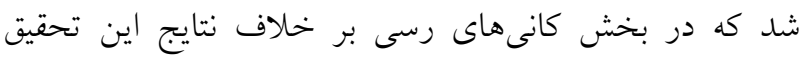
كانى اسمكتايت بيشتر در بخشهاى مربوط به واحدهاى

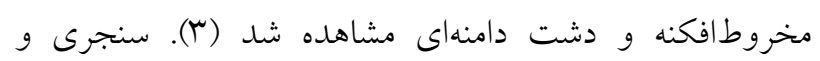
همكارن (YN) در جنوب شرق ايران گزارش كردند كه با حركت از سمت واحدهاى مخروطافكنه بهسمت دشتهاى دامنهاى و دشتهاى آبرفتى بهدليل افزايش سطح آب زيرزمينى،

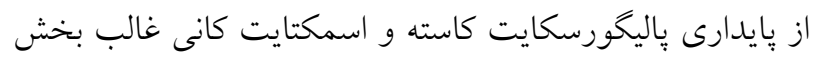
رس خاك مىشود. بهطور كلى هر دو سامانه در بيان تفاوت
بهصورت غيرمستقيم در ويزگكىهاى برخى از افقتهـاى سـامانه

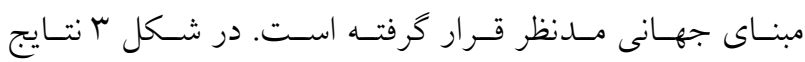

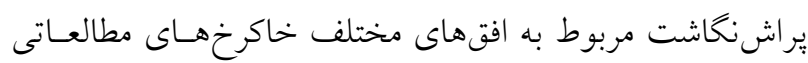

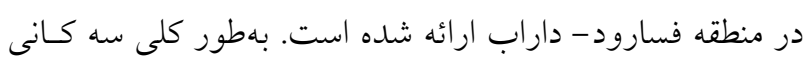

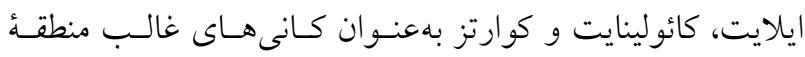

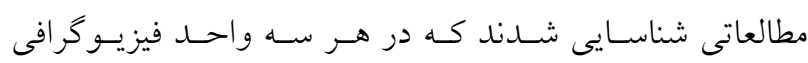

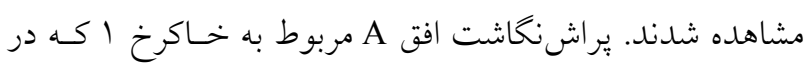

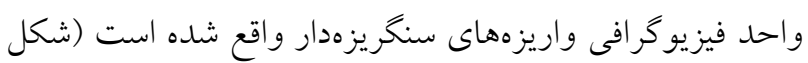

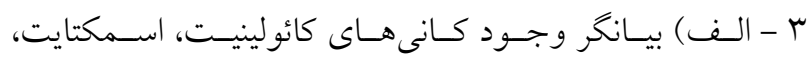

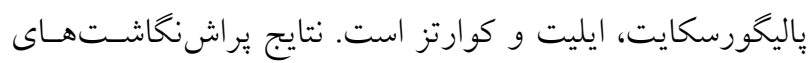

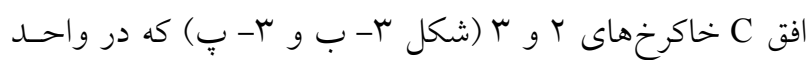

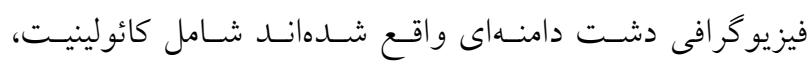
كلريت، ايليت، كوارتز و كائولينيت، اسمكتيت، ايليت و كـوارتز

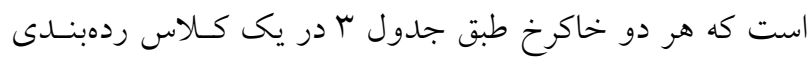

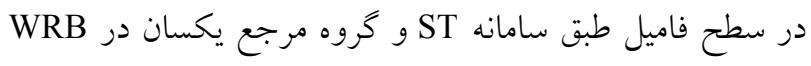

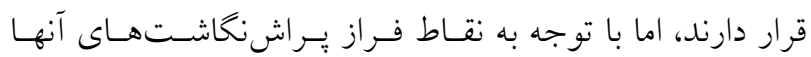

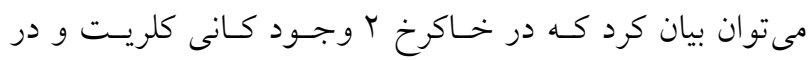

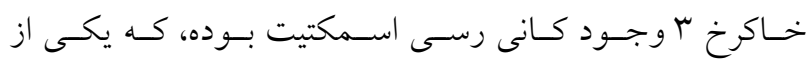

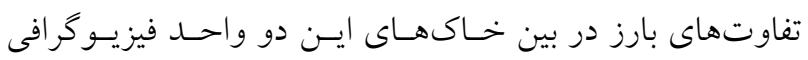
است كه توسط هـيجيـــ از دو سـامانه ردمبنـدى (ST,WRB)

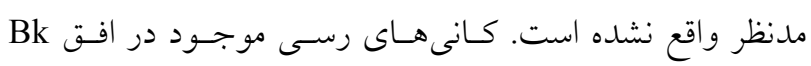

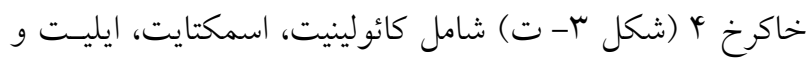

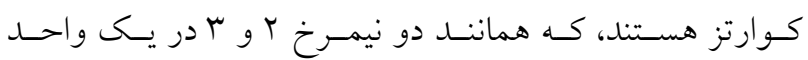
فيز يو گرافى قرار دارد.

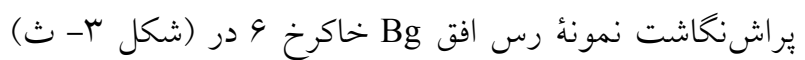

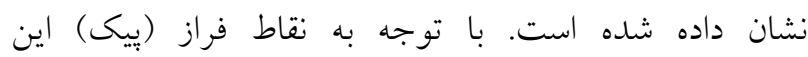

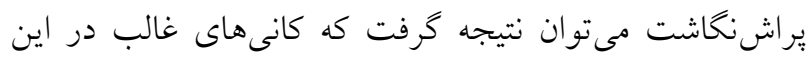

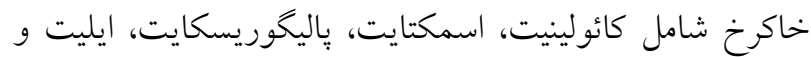

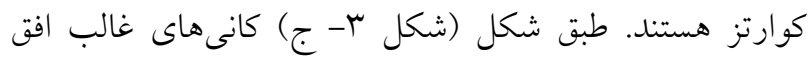
Bw

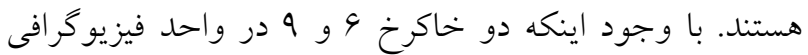
دشت دامنهاى و دشت آبرفتى واقع شدهاند؛ در دو خاكرخ 9 و ور 

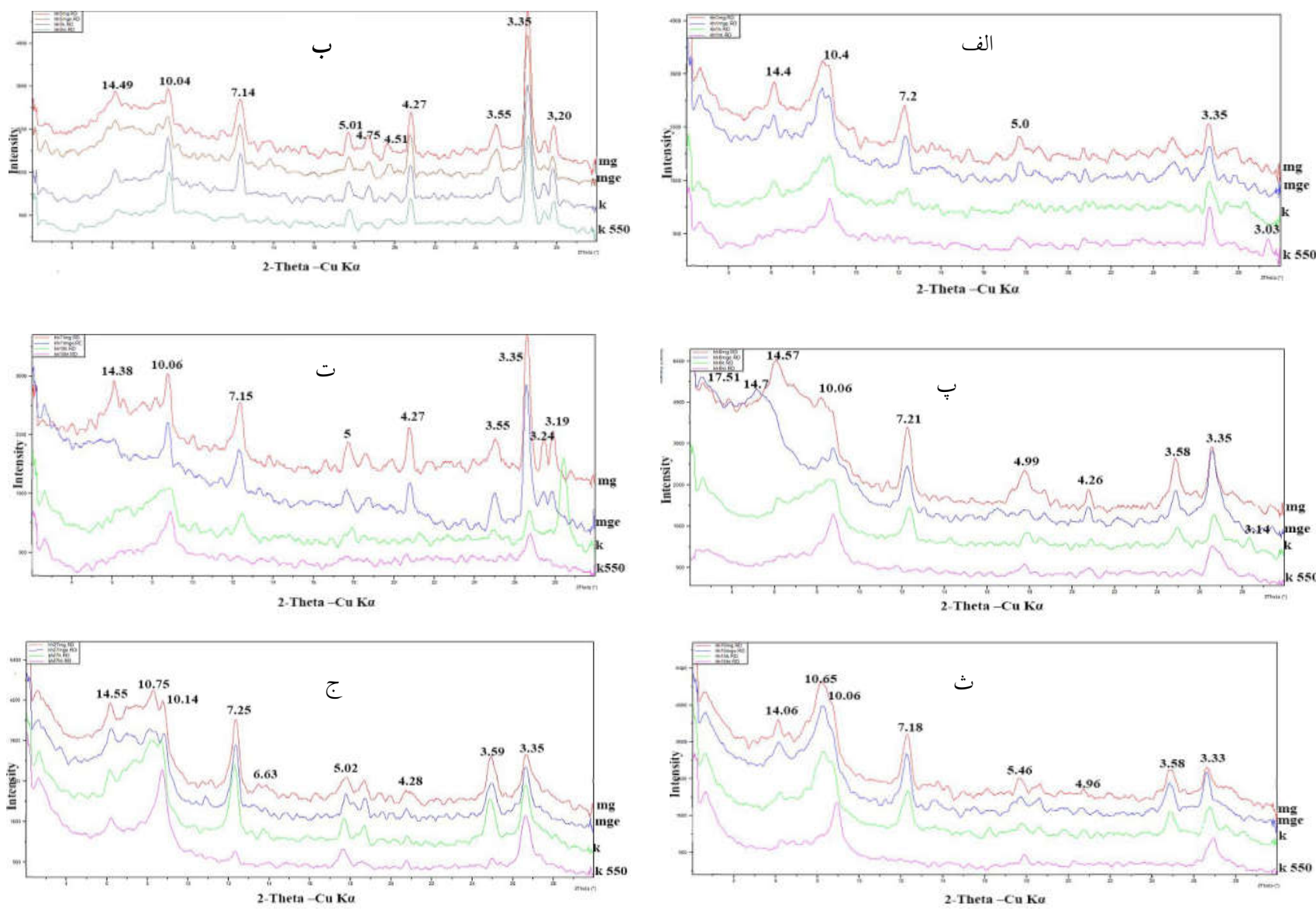

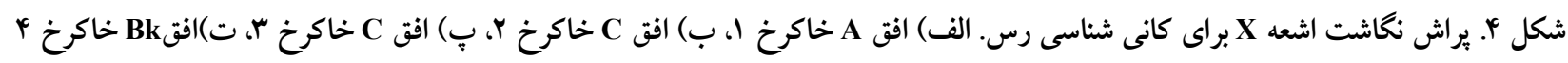

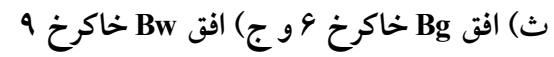

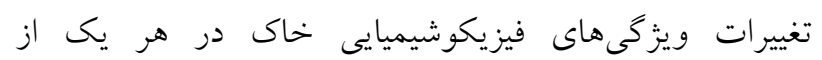

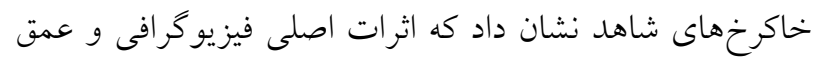

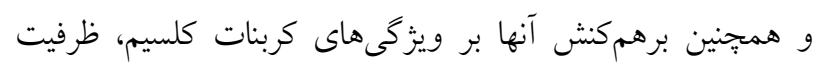

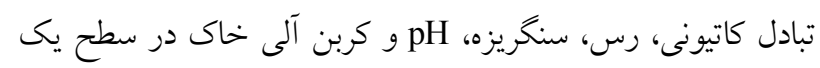

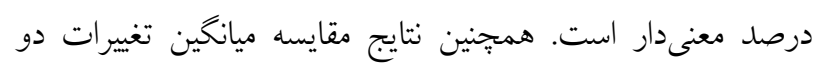

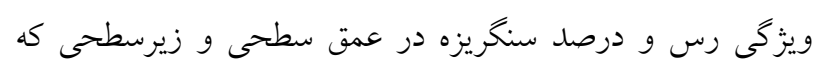

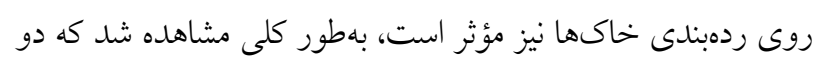

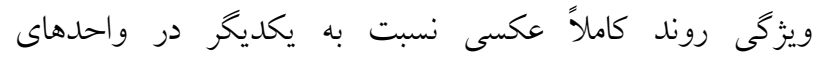

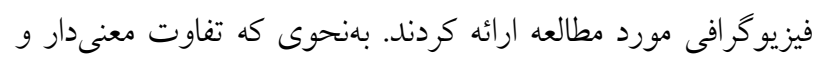

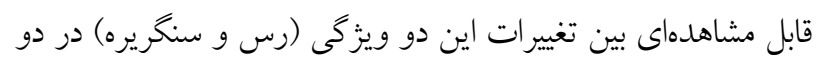

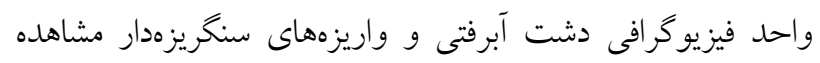

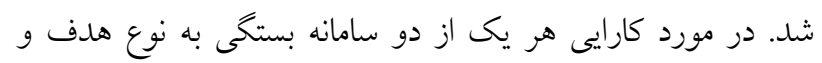

ويزگى هاى كانىشناسى خاكهاى مورد مطالعه بهويزه در

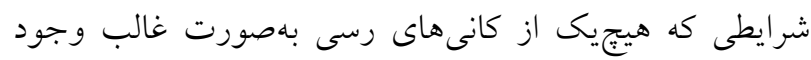

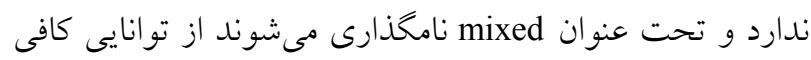

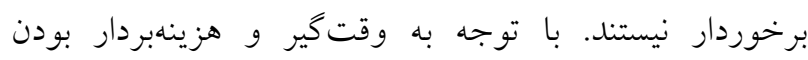

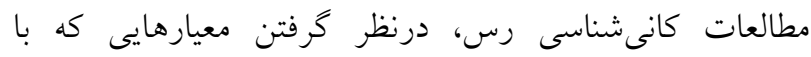

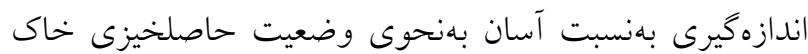
را بيان كند، مىتواند براى بهرهبردارى از خاكها بسيار مفيد

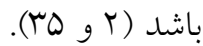

\section{نتيجه گيرى}

نتايج اين تحقيق بيانكر اين است بر اساس تحليل آمارى تجزيه

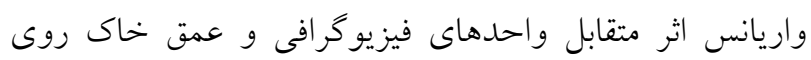




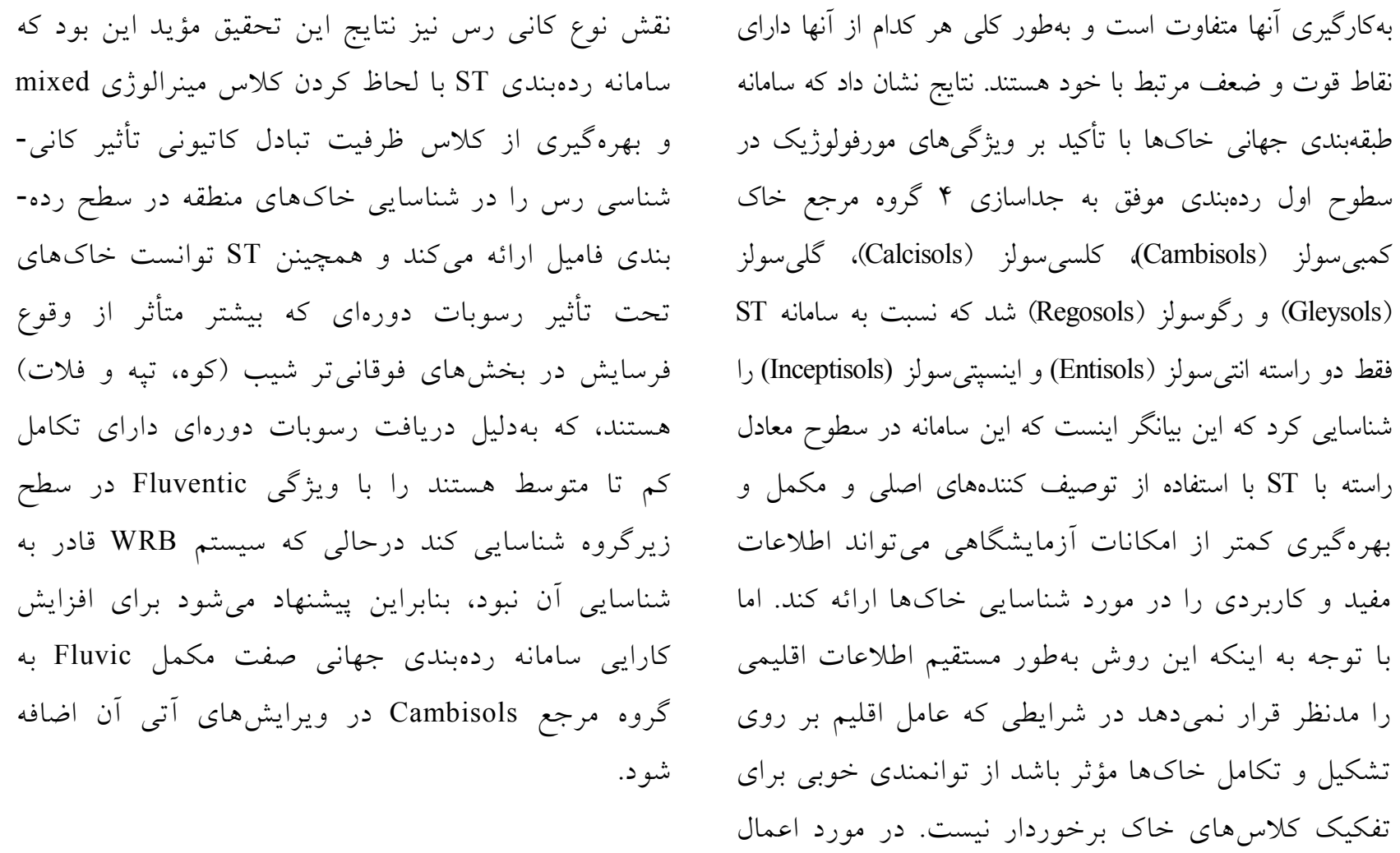

\section{منابع مورد استفاده}

1. Anjos L. H., M. R. Fernandes, M. G. Pereira and D. P. Franzmeier. 1998. Landscape and pedogenesis of an oxisols inceptisols-ultisols sequence in Southeastern Brazil. Soil Science Society of America Journal 62: 1651-1659.

2. Bahmani, M., M. H. Salehi and I. Esfandiarpour Boroujeni. 2014. Comparison of American soil taxonomy and WRB classification systems in describing the properties of some soils in arid and semi-arid regions of central Iran. Journal of Agricultural and Natural Resources Sciences and Technology 67: 11-21.

3. Bahoorzehi, M. A., M. H. Farpoor and A. Jafari. 2016. Genesis and development of soils along different geomorphic surfaces in Kouh Birk Area, Mehrestan City. Journal of Water and Soil 30: 555-568. (In Farsi).

4. Buol, S. W. 2003. Soil Genesis and Classification (5th ed.). Iowa State University Press, Amesterdam.

5. Cline, M. G. 1949. Basic principles of soil classification. Soil Science 67(2): 81-91.

6. Esfandiarpour Boroujeni, I., M. H. Farpoor and A. Kamali. 2011. Comparison between soil taxonomy and WRB for classifying saline soils of Kerman Province. Journal of Water and Soil 25: 1158-1171. (In Farsi).

7. Esfandiarpour-Borujenia, I., Z. Mosleh and M. H. Farpoor. 2018. Comparing the ability of soil taxonomy (2014) and WRB (2015) to distinguish lithologic discontinuity and an abrupt textural change in major soils of Iran. Catena 63-71.

8. Eswaran, H., T. Rice, R. Ahrens and B. A. Stewart (Eds.). 2002. Soil Classification: A Global Desk Reference. CRC Press, Boca Raton, FL.

9. Gee, G. W. and J. W. Bauder. 1986. Particle-Size Analysis 1. Methods of Soil Analysis: Part 1-Physical and Mineralogical Methods, (Methods of Soil Analysis).

10. Gerasimova, M. I. 2010. Chinese Soil Taxonomy: between the American and the international classification systems. Eurasian Soil Science 43(8): 945-949.

11. Golmohammad, H., H. Ramezanpour and S. Rezapour. 2016. Study on some soil properties as affected by different slope position and aspect in mountainous landform with different parent materials in Masouleh. Water and Soil Science 26(2-2): 53-66.

12. Havaee, S., A. Kamali and N. Toomanian. 2019. Appraisal of the world reference base for soils (WRB) and US soil taxonomy for classification of developed soils of Zayandeh-rud River's upper Terrace. Journal of Water and Soil 33(1). (In Farsi).

13. Hudson, B. D. 1990. Concepts of soil mapping and interpretation. Soil Survey Horizons 31: 63-73. 
14. Iran Metrological Organization. 2018. Iran Meteorological Organization, Climate Information, Qazvin synoptic station, Qazvin, Iran. Available at: http://www.irimo.ir/eng/index.php.

15. Jenny, H. 2011. Factors of Soil Formation-A System of Quantitative Pedology. Dover Inc, New York.

16. Karimi A., H. Khademi and A. Jalalian. 2009. Genesis and distribution of palygorskite and associated sediments of southern Mashhad. Iranian Journal of Crystallography and Mineralogy 16: 545-558. (In Farsi).

17. Khosravani, P., M. Baghernejad, A. Abtahi and R. Ghasemi. 2019. Investigation and identification of different clay minerals along a toposequence (A case study: Fasarood-Darab city). 16th Iranian soil congress. University of Zanjan. Soil Genesis and Classification Section. (In Farsi).

18. Maleki, S., F. Khormali, F. Kiani and A. Karimi. 2019. Effect of slope direction and position on some physical and chemical properties of soil in sloping loamy lands, Toshan region, Golestan province. Soil and Water Conservation Research (Agricultural Sciences and Natural Resources) 20(3): 93 -112.

19. Moazallahi, M. and M. H. Farpoor. 2012. Soil Genesis and Clay Mineralogy along the Xeric-Aridic Climotoposequence in South Central Iran.

20. Moghbeli, Z., H. R. Owliaie, S. Sanjari and E. Adhami. 2019. Genetic study of soil-landscape relationship in arid region of faryab, Kerman province. Journal of Water and Soil 33(2): 333-347. (In Farsi).

21. Mohajeri, P., P. Alamdari and A. Golchin. 2016. The effect of slope positions on physical and chemical properties of soils on low and high rows in Deilman region of Guilan province. Journal of Water and Soil 30(1): 162-171.

22. Morand, D. T. 2010. The world reference base for soils (WRB) and soil taxonomy: an initial appraisal of their application to the soils of the Northern Rivers of New South Wales. In Proceedings of the 19th World Congress of Soil Science; Soil Solutions for a Changing World (pp. 1-6).

23. Mousavi, S., R. Sarmadian, F. Alijani and Z. Abass Taati. 2017. Land suitability evaluation for irrigating wheat by geopedological approach and geographic information system: A case study of Qazvin plain, Iran. Eurasian Journal of Soil Science 6(3): 275-284.

24. Muir, J. W. 1962. The general principles of classification with reference to soils. Journal Soil Science 13(1): 22-30.

25. Nelson, R. E. 1982. Carbonate and gypsum. PP. 181-197. In: Page, A. L. (Eds.), Methods of Soil Analysis. American Society of Agronomy, Madison.

26. Pajand, M. J., H. Emami and A. Astaraee. 2015. Relationship between topography and some soil properties. Water and Soil 29(6): 1699-1710.

27.Roca, P. N. and M. S. Pazos. 2002. The WRB applied to Argentinian soils: two case studies. European Soil Bureau, Research Report No. 7. Latvia University of Agriculture, Jelgava, Latvia.

28. Sanjari, S., M. H. Farpoor, M. K. Eghbal and I. Esfandiarpoor. 2011. Genesis, micromorphology and clay mineralogy of soils located on different geomorphic surfaces in Jiroft area. Journal of Water and Soil 25: 411-425. (In Farsi).

29. Sarmadian, F., S. R. Mousavi, M. Iqbal, A. Keshavarzi and M. Sadeghnejad. 2014. Investigation the variation of soil mapping units using geopedological approach. Acta Advances in Agricultural Sciences 2 (5): 1-9.

30. Sarmast M., M. H. Farpoor and I. Esfandiarpour Boroujeni. 2016. Comparing soil taxonomy (2014) and updated WRB (2015) for describing calcareous and gypsiferous soils, Central Iran. Catena 145: 83-91.

31. Sarshoghe, M. 2010. The Effect of aspect and slope position on soil morphological, physicochemical and mineralogical properties in chelgerd region. Shahrekord University, Iran (MSc thesis).

32. Schoeneberger, P. J., D. A. Wysocki and E. C. Benham. 2012. Soil Survey Staff. Field book for describing and sampling soils, 3nd version. Natural Resources Conservation Service. National Soil Survey Center, Lincoln.

33. Secu, C. V., C. Patriche and I. Vasiliniuc. 2008. Aspects regarding the correlation of the Romanian soil taxonomy system (2003) with WRB (2006). Грунтознавство 9: 56-62.

34. Soil Science Division Staff. 2017. Soil survey manual." USDA handbook.

35. Soil Survey Staff. 2014. Keys to Soil Taxonomy.11th ed., NRCS, USDA, USA.

36. Sumner, M. E. and W. P. Miller. 1996. Cation exchange capacity and exchange coefficients. Methods of Soil Analysis Part 3-Chemical Methods, (Methodsofsoilan3).

37. Toomanian N., A. Jalalian and M. K. Eghbal. 2003. Application of the WRB (FAO) and US taxonomy systems to gypsiferous soils in Northwest Isfahan. Iranian Journal of Agriculture Science of Technology 5: 51-66.

38. Van Wambeke, A. R. 2000. The Newhall Simulation Model for estimating soil moisture and temperature regimes. Department of Crop and Soil Sciences. Cornell University, Ithaca, NY. USA.

39. Walkley, A. and I. A. Black. 1934. An examination of the Degtjareff method for determining soil organic matter, and a proposed modification of the chromic acid titration method. Soil Science 37(1): 29-38.

40. Wondzell, S. M., C. L. Cunningham and D. Bachelet. 1996. Relationships between landforms, geomorphic processes, and plant communities on a watershed in the northern Chihuahuan Desert. Landscape Ecology 11: 351-362.

41. WRB. 2015. World reference base for soil resources 2014, update 2015. International soilclassification system for naming soils and creating legends for soil maps. World SoilResources Reports No. 106. FAO, Rome. 


\title{
Comparison of the Efficiency of Soil Taxonomy (2014) and WRB (2015) Systems in the Study of Soil Variations in Different Landform Positions
}

\author{
P. Khosravani, M. Baghernejad*, A. Abtahi and R. Ghasemi ${ }^{1}$
}

(Received: April 23-2020; Accepted: January 13-2021)

\begin{abstract}
Soil classification in a standard system is usually defined based on information obtained from properties and their variations in different map units. The aim of this study was to compare soil genesis and morphological characteristics in different landforms with WRB and Soil Taxonomy (ST) Systems. From nine studied profiles, six profiles were selected as representative profiles and dug in Colluvial fans, Piedmont plain, and Alluvial plain physiographic units, respectively. Then, the soils were classified according to the pattern of the two systems. Also, variation analysis of variance (ANOVA) and comparing means were used to quantify interested soil properties. The results of soil physiochemical properties at different landform positions were significant based on analysis of variance of the effect of physiographic units and soil depth at the level of $1 \%$. Soil classification results based on WRB indicated that WRB were recognized four reference soil groups (RSG) included Regosols, Cambisols, Calcisols, and Gleysols at the first level of WRB classification in comparison of ST with recognizing two order Entisols and Inceptisols could separate more soils. The soils were located on the alluvial plain with a high groundwater level in the WRB due to the creation of restrictive conditions for root development in contrast to the ST called "Aquepts" in the suborder level but in a WRB is classified as the "Gleysols" RSG. On the other hand, ST, unlike WRB, used the Shallow criteria at the family level to describe the shallowness of soils and the limitations of root development. Generally, the efficiency of each system varies despite the differences in their structure and depending on the purpose of using them.
\end{abstract}

Keywords: Geomorphic surface, Soil classification, Clay mineralogy, Soil morphological properties

1. Soil Science Department, Faculty of Agriculture, University of Shiraz, Shiraz, Iran.

Corresponding author, Email: majidbaghernejad@yahoo.co.uk 